\title{
New Insights Into the Minimum Teeth Number and Modification Coefficient of Standard Involute Gears Without Undercutting
}

Hongshen Zhang ( $\square$ hongshen@kust.edu.cn )

प्र००र https://orcid.org/0000-0003-3363-0319

Jianing He

Kunming University of Science and Technology

\section{Original Article}

Keywords: standard involute gear design, standard involute gear manufacturing, undercutting phenomenon, minimum teeth, minimum modification coefficient

Posted Date: January 15th, 2021

DOI: https://doi.org/10.21203/rs.3.rs-145370/v1

License: (c) (1) This work is licensed under a Creative Commons Attribution 4.0 International License.

Read Full License 


\title{
New insights into the minimum teeth number and modification coefficient of standard involute gears without undercutting
}

\author{
Hongshen Zhang ${ }^{1 *}$, Jianing $\mathrm{He}^{1}$ \\ (1. Faculty of Mechanical and Electrical Engineering, Kunming University of Science and \\ Technology, 650500 Kunming, China; *. Corresponding author: hongshen@kust.edu.cn, ORCID:
}

0000-0003-3363-0319.)

\section{CRediT author statement}

Hongshen Zhang: Conceptualization, Editing Data, Writing- Original draft preparation.

Jianing He: Methodology, Editing.

\begin{abstract}
The calculation equations for the minimum teeth number and the minimum modification coefficient of standard involute gears without undercutting are inaccurately described and researched in many studies. These errors are knowledge blind spots in mechanical engineering that have been introduced into the design and manufacturing of standard involute gears. Furthermore, these errors are continually imparted to tens of thousands of students in colleges every yearly. Racks have been incorrectly regarded as the rack-shaped cutters in the derivation of the calculation equations. The theoretical research, numerical simulation and experiments of the undercutting phenomenon of standard involute gears manufactured using rack-shaped cutters are presented. Firstly, theoretical analysis and calculation of the minimum teeth number and the minimum modification coefficient of standard involute gears without undercutting are performed. Subsequently, the correct minimum teeth number and the minimum modification coefficient without undercutting are deduced. The computer simulations of the theoretical calculations are then examined considering the necessary cases. Experiments of standard involute spur gears with $z=10$, 12, 17 and 22 are conducted, thereby validating the research. This study addresses the long-standing errors regarding the traditional undercutting phenomenon and provides an effective theoretical guide for gear design and manufacturing.
\end{abstract}

Keywords: standard involute gear design; standard involute gear manufacturing; undercutting phenomenon; minimum teeth; minimum modification coefficient

\section{Introduction}

Gear design optimization has become more of a necessity than ever before[1]. Involute gear transmission has been widely used because of its unique technical advantages. Research on stress distribution [2, 3], tolerance analysis[4] noise[5], vibration[6] and thermal analysis[7] in geared systems have been centred on gear-specific components. However, for the meshing of specific teeth number in a gear pair, an interference exists between the tip of the teeth on the pinion and the fillet or root of the teeth on the gear [8]. Undercutting at the pinion root may affect the load distribution and meshing character amongst pairs of involute gear teeth in simultaneous contact [9]. Therefore, the conditions for avoiding undercutting have been extensively studied and discussed in many technical literature references, such as Litvin [10], Chao [11] and Ye[12]. The calculation equations for the minimum teeth number without undercutting $z_{\min }$ and the minimum modification coefficient without undercutting $x_{\min }$ of standard involute gears are inaccurately described in many textbooks wroldwide, such as the Design of machine elements, Mechanical Engineering Design, and Foundation of Machine Design. These errors have also been introduced into the design and manufacture of involute gears [13, 14]. Thus, gears with undercutting defects have been used in a variety of transmission systems. Furthermore, this information is continually imparted to tens of thousands of students in universities yearly. A certain degree of undercutting can improve the meshing environment and the stability of gear pairs. However, the meshing region length of the tooth surface decreases when the undercutting of tooth exceeds a certain level whilst the strength of the roots decrease, which may cause the tooth to break. Therefore, studies on the undercutting 
phenomenon of gears are significant to its design, production and application.

The involute gear is extensively used in many kinds of mechanisms and machines, from can openers to aircraft carriers. Involute gears can be manufactured using finger cutters, rack cutters, gear shapers, and hobs. In traditional theory, the meshing conditions of involute gear (generated using a rack cutter) are well-defined when considering the meshing of the rectilinear profile of the rack cutter with an involute tooth gear $[15,16]$. In the involute gear mesh, undercutting and meshing interferences occur when the teeth number is smaller than a certain value. Instead of defining the geometry of the gear to manufacture, designers often define the geometry of the rack conjugated to the gear, that is, the basic rack. This approach makes it easy for the manufacturer to find the geometry of the tool to cut the gear [17]. However, in the derivation process of the minimum teeth number without undercutting, the rack cutter fillet has an evident influence on the result, which has been omitted in many mechanical engineering textbooks for many years. The addendum of the standard involute rack-shaped cutter is higher than that of the rack because a clearance ' $c$ ' exists at the top of the cutter.

Considering top clearance $c$ in the article, the theoretical $z_{\min }$ of standard involute gear is specified in this article. In addition, $x_{\min }$ with fewer teeth (fewer than $z_{\min }$ ) is analyzed. The minimum teeth number and the modification coefficients of standard involute gears are simulated using a specific computer program to verify the validity of the theoretical studies. The experiments of undercutting phenomenon of standard involute spur gears are also conducted.

\section{Minimum teeth number of involute gears without undercutting in the literature}

Interference and its attendant undercutting can be prevented by avoiding gears with few teeth. The teeth profile enlarge as its number decreases for a fixed diameter gear. Then, the dedendum will exceed the radial distance between the base circle and the pitch circle in the manufacturing process, and tooth undercutting will occur.

Regarding the undercutting issue, one of the earlier books that referred to gear manufacturing was compiled by the Former Soviet Union (FSU) mechanical expert I. I. Semenchenko in 1944 [18]. The precise definition of gear undercutting and the $z_{\min }$ of the standard involute gear are provided. The noninterference minimum teeth of the meshing gear with the rack is $z_{1 \mathrm{~min}}=17$ when the pressure angle $\alpha=20^{\circ}$ and $h_{a}^{*}=1^{1}$; and if the rack is replaced by a rack-shaped cutter, then $z_{1 \min }=20.52$ [18]. The $z_{\min }$ of the rack-shaped cutter is larger than that of the rack because the clearance coefficient $c^{*}$ was added into the equation. However, $c^{*}=0.2$ in his study, which is inconsistent with the modern standard involute gears.

However, in many mechanical engineering textbooks, rack cutter is mistakenly regarded as rack when the minimum teeth number without undercutting is deduced, thereby causing the misconception of the undercutting phenomenon. Undercutting is also discussed in another book by FSU professor лнтвин, in which the undercutting phenomenon was reported to occur when the spur gear teeth number is less than 17 [19]. In the Design of Machine Elements book compiled by professor Spotts in the Northwestern University of America, undercut not only weakens the tooth, but also removes a small portion of involute adjacent to the base circle, and the loss of involute curves may cause a serious reduction of the contact length. His study also showed that the undercutting phenomenon disappears when the $z_{\min }$ is larger than or equal to $17[20,21]$.

In the literature Mechanical Engineering Design written by Edward and Mischke, the conditions for avoiding of the traditional undercutting of gears are defined; and they found that the smallest number of pinion teeth was 18 teeth to a $\alpha=20^{\circ}$ full-depth teeth [22]. In Gears compiled by Houghton in England, the $z_{\min }$ of standard involute spur gear is 17 under the pressure angle $\alpha=20^{\circ}$ [23]. In the Gear Handbook of America, Dudley reported that the undercutting of standard involute spur gears can be avoided when the number of teeth is larger than or equal to 18 [24]. In the Machine Element

\footnotetext{
${ }^{1}$. In the original context, $h_{a}^{*}=m, m=1$, where $h_{a}^{*}$ is the coefficient of addendum height, and $m$ is the
} module of gear. 
in Mechanical Design by Mott, the responsibility of designers is to ensure that interference does not occur in a given application; and the best way to avoid undercutting is to control the $z_{\min }$ of the standard spur gear (pressure angle is $20^{\circ}$ ) to larger than or equal to $18[25,26]$. Budynas also proved that the smallest number of pinion teeth to mesh with a rack is 18 for a $\alpha=20^{\circ}$ full-depth tooth[27].

A generalized approach for defining the undercutting phenomenon of involute teeth was proposed by Alipiev. In the proposed approach, apart from the traditional undercutting, type I, two additional undercutting cases, types $\mathrm{II}_{\mathrm{a}}$ and $\mathrm{II}_{\mathrm{b}}$, were described. An additional boundary condition for avoiding types $\mathrm{II}_{\mathrm{a}}$ and $\mathrm{II}_{\mathrm{b}}$ undercutting was drawn, and the maximum radius value of the rack cutter fillet, wherein no undercutting occurred, was specified [28].

Undercutting phenomenon is defined in the book of Design of Machinery compiled by $\mathrm{Pu}$ in China [29]. Fig. 1 shows that if the intersection point of the tool top line and the mesh line surpasses the limit mesh point $N_{l}$, then gear profile of involutes will be removed by the cutting tool. A similar definition is also described by Sun[30] and Ye [31]. The minimum numbers of teeth of standard involute spur gear without undercutting in the two books are both 17. The academic group of the essay is dedicated to the gear design and manufacturing research, and some preliminary results are acquired, including the minimum number of teeth of standard involute gears without undercutting and the undercutting of involute spur gear with different pressure angles. During the study of the minimum number of teeth of standard involute gear teeth without undercutting, the concept of 'rack cutter has been mistakenly regarded as rack in the study of the minimum number of teeth without undercutting in many textbooks' is promoted for the first time[32] by the researchers. In the studies of involute spur gear undercutting with different pressure angles based on the VB programme and the neural network method, undercutting of involute gear with different pressure angles, namely, $14.5^{\circ}, 22.5^{\circ}$, and $25^{\circ}$, are discussed[33-37].

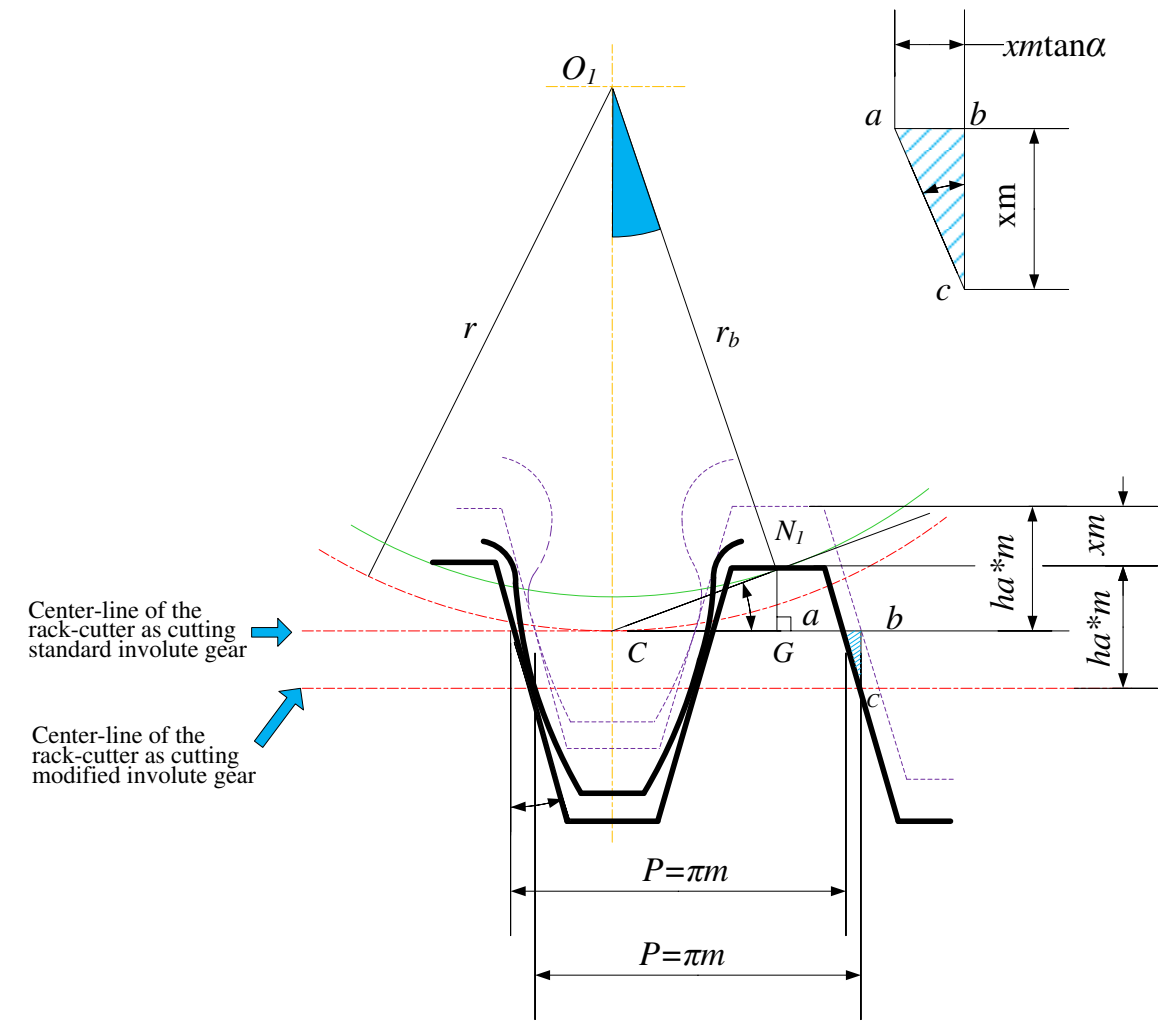

Fig. 1 Undercut and modification of standard involute gear

Researchers from all over the world are dedicated to the gear design and manufacturing research and a significant amount of important findings have been acquired. For instance, a gear tooth mathematical model is developed to investigate the tooth undercutting of curvilinear-tooth gears via differential geometry and the numerical method[38]. Mimmi gives a contribution to the internal 
gear theory by analytically determining the limits on the design parameters for avoiding undercutting by using the limit curve concept[39]. Chiang proposes a geometric approach to determining the grinding wheel profile and the conditions to avoid undercutting[40]. However, many problems remain unsolved. As previously mentioned, in many textbooks, rack cutter has been mistakenly regarded as rack when minimum teeth without undercutting are developed, which causes the misconception of the undercutting phenomenon. Though the undercutting phenomenon of the involute gear cut by rack-shaped cutter was mentioned by Semenchenko, the top clearance coefficient $c^{*}$ used in his study did not conform to modern gears manufacturing. Furthermore, modified involute gears are required in certain situations. However, reports on the modification coefficient of the gear manufactured by rack cutter remain unsolved. Therefore, in the following sections, the minimum number of teeth and the modification coefficient of the standard involute gear undercutting phenomenon are comprehensively discussed.

\section{$3 z_{\min }$ of standard involute gear manufactured by rack and rank-shaped cutters \\ $3.1 z_{\min }$ of standard involute gear manufactured by rack \\ 3.1.1 $z_{\min }$ of standard involute spur gear}

According to the undercutting phenomenon of traditional theory, undercutting occurs if the rack top line exceeds the meshing limit $N_{1}$ (Fig. 1) in the involute gears manufacturing process. Therefore, the top line of the rack must be under the theoretical contact point. The diagram of the traditional involute gear manufacturing by rack is shown in Fig. 2. The cutter (rack) centerline is tangent to the pitch circle.

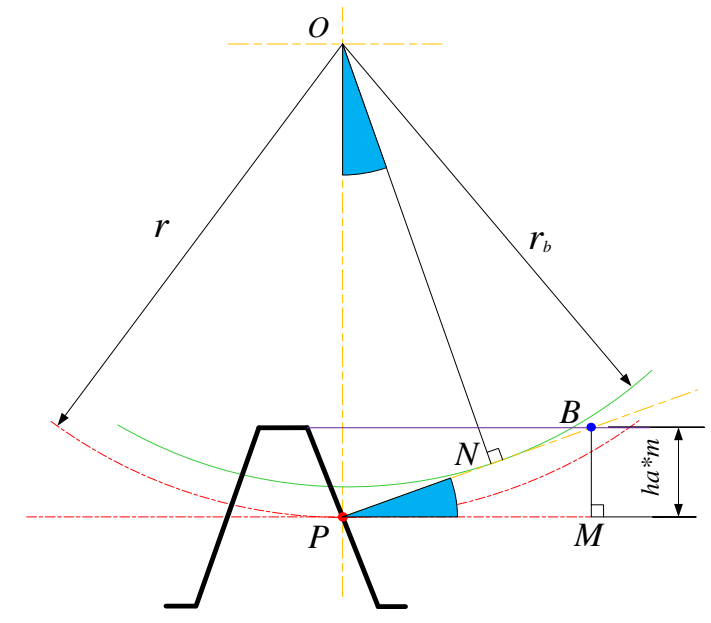

Fig. 2 Diagram of traditional involute gear manufacturing with standard rack

The tip-line of the rack should be under the ultimate contact point of teeth $N$ (Fig.2) to avoid undercutting. In other words, the length of PB should be shorter than that of PN, which means that the condition for non-undercutting can be expressed by the inequality

$$
P B \leq P N \text {. }
$$

Notably, $P B$ and $P N$ belong to triangles $P B M$ and $O P N$, respectively, and they can be calculated as follows:

$$
P B=h_{a}^{*} m / \sin \alpha, P N=r \sin \alpha,
$$

where $r$ is the radius of reference circle, and $m$ is the module of gear. Considering $r=m z / 2(z$ is the tooth number of gear) and integrating the Eqs. (1) and (2), the traditional condition for nonundercutting is written as follows:

$$
z_{\min }=2 h_{a}^{*} m / \sin ^{2} \alpha \text {. }
$$

Given the default values $h_{a}^{*}=1$ and $\alpha=20^{\circ}$, the minimum tooth number $z_{\min }=17.097$ (rounded to 17). That is, the minimum number of teeth for spur gears without undercutting is 17. 


\subsection{2 $z_{\min }$ of involute helical gear and bevel gears}

For standard involute helical gears, the relation between the tooth numbers of helical gear $z_{h}$ and the tooth numbers of its equivalent spur gear $z_{v h}$ is written as follows[31]:

$$
z_{v h}=z_{h} / \cos ^{3} \beta \text {, }
$$

where $\beta$ is the helix angle of the gear. Thus, the minimum teeth number for the helical gear $z_{h \min }$ is

$$
z_{h \min }=z_{v h \min } \cos ^{3} \beta \text {. }
$$

As mentioned in Section 3.1.1, the minimum number of teeth of equivalent spur gear without undercutting is also $17\left(z_{v h}=17\right)$. Hence, considering $\beta=15$ and $h_{a n}^{*}=1\left(h_{a n}^{*}\right.$ is the coefficient of addendum height in normal direction), the minimum teeth number of helical gears without undercutting is $z_{h \min }=15.32 \approx 16$ based on the Eq. (5).

Straight bevel gears are the most widely used because they are easy to design and manufacture. Hence, only straight bevel gears are discussed in this study. The back cone of the bevel gear can be unfolded imaginarily into a sector gear, which can be filled up to the full gear. The new full gear is called the equivalent spur gear of the original bevel gear. The tooth profile of the virtual gear is almost the same as that of the bevel gear at the large end, and its module and pressure angle are the same as those of the bevel gear. However, the $c^{*}$ of bevel gear is $0.2(m \geq 1)$, which is different from that of the spur gear. The tooth number of virtual gear $z_{v b}$ is associated with the tooth number $z_{b}$ and the reference cone angle $\delta$ of the original bevel gear as follows:

$$
z_{v b}=z_{b} / \cos \delta \text {. }
$$

The minimum tooth number without undercutting for the equivalent gear of the bevel gear is equal to the $z_{\min }$ of the spur gear. Thus, the minimum teeth number for the bevel gear without undercutting $z_{b \min }$ is

$\mathrm{z}_{b \min }=\mathrm{Z}_{v b \min } \cos \delta$.
Substituting $\mathrm{z}_{v b \min }=17$ and $\delta=35^{\circ}$ into formula (7) yields $z_{b \min }=13.93$ (rounded to 14).

The minimum tooth numbers of the helical and bevel gears without undercutting are both less than those of the spur gear. However, in the analysis process of the minimum tooth numbers without undercutting based on the traditional theory, the $c$ of rack-shaped cutter is ignored in the calculation, which has a remarkably effect on the result. Thus, the effect of $c$ is discussed in the next section.

\section{$3.2 z_{\min }$ of involute gear manufactured rank-shaped cutters considering the effect of $c$}

Rack-shaped cutter is widely used in the actual manufacturing process of involute gears. In traditional theories, undercutting occurs when the rack addendum goes beyond the mesh limit point, but the actual gear machining process is ignored. In practice, the $c$ (the height fillet portion, $c=c^{*} m$ ) must be added on the cutter top to generate the radial clearance portion [36]. Therefore, in the actual manufacturing process of involute gears, the limit meshing point is not the intersection point of the meshing line and the addendum line of the cutter, but the crossover point of the meshing line and the top line of the fillet portion of the rack-shaped cutter, as shown in Fig. 3. The cutting edge between the tip and the addendum lines is not a straight line, and the corresponding profile cut is not involute. Therefore, if the minimum teeth number without undercutting gained from the traditional theory is used to guide the manufacture of involute gears, then involute portion removed in reality will be more than that and the degree of undercutting will be correspondingly worse. 


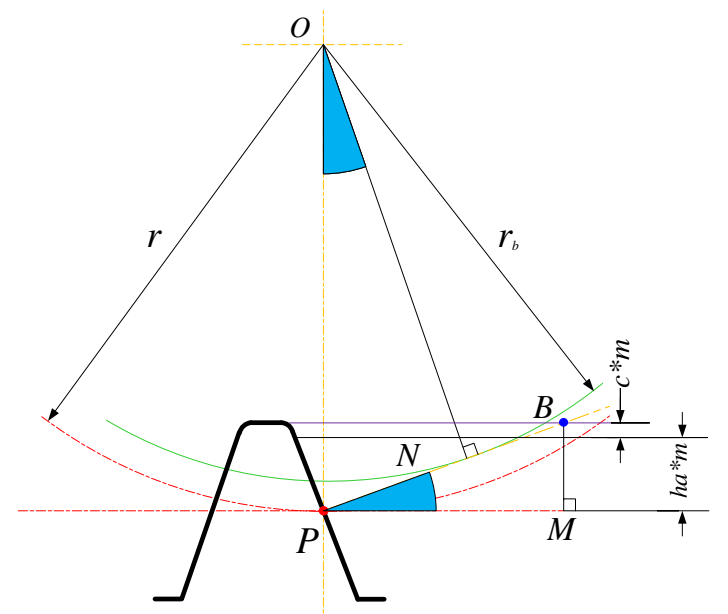

Fig. 3 Standard involute gear manufacturing by a standard rack-shaped cutter

Therefore, if standard involute spur gears are manufactured with a rack-shaped cutter, then $z_{\min }$ without undercutting can be calculated by the inequality $P B \leq P N$, as shown in Fig. 3, with the following result:

$$
z_{\min }=2\left(h_{a}^{*}+\mathrm{c}^{*}\right) / \sin ^{2} \alpha \text {. }
$$

If the default values are $\mathrm{h}_{\mathrm{a}}^{*}=1, \mathrm{c}^{*}=0.25$, and $\alpha=20^{\circ}, \mathrm{z}_{\min }=21.37$ (rounded to 22). That is, the $\mathrm{z}_{\min }$ of the spur gear manufactured with a rack-shaped cutter is 22 .

As previously mentioned, the minimum tooth number for the helical gear without undercutting is also $22\left(z_{v h}=22\right)$. Considering $\beta=15^{\circ}, z_{v h \min }=22$ and $h_{a n}^{*}=1$, the minimum teeth number of the helical gear without undercutting is $z_{h \min }=19.8$ (rounded to 20) based on the Eq. (5).

The minimum tooth number for the equivalent gear of the bevel gear without undercutting is equal to the minimum teeth number of the spur gear without undercutting, which means that $z_{v b \min }=22$.

For bevel gear manufactured with a rack-shaped cutter with a bottom clearance, $z_{b \min }$ (rounded to 18 ) is obtained by substituting $z_{v b \min }=22$ and $\delta=35^{\circ}$ in formula (7), as shown in Table 1 .

Table $1 z_{\min }$ of standard involute gears

\begin{tabular}{|c|c|c|}
\hline Standard Involute Gears & Traditional theories & $\begin{array}{c}\text { Manufactured by rack- } \\
\text { cutter }\end{array}$ \\
\hline Spur gears & $z_{\min }=17$ & $z_{\min }=22$ \\
\hline Helical gears & $z_{\min } \approx 16\left(\beta=15^{\circ}\right)$ & $z_{\min } \approx 20\left(\beta=15^{\circ}\right)$ \\
\hline Straight bevel gears & $z_{\min } \approx 14\left(\delta=35^{\circ}\right)$ & $z_{\min } \approx 18\left(\delta=35^{\circ}\right)$ \\
\hline
\end{tabular}

Considering the bottom clearance $c$ of the rack-shaped cutter, the minimum teeth numbers of the three kinds of involute gears are high. The results are strikingly different from those of the traditional theories and are in accordance with the actual situation employing the rack-shaped cutter. This phenomenon necessitates a theoretical conference on involute gears manufacturing.

\section{Minimum modification coefficient $x_{\min }$ of the standard involute gear}

\section{1 $x_{\min }$ of the standard involute gear in conventional theory}

Owing to their perfect interchangeability, standard involute gears are widely used in many kinds of machines. However, these gears also have some disadvantages; for example, the number of teeth should not be less than $z_{\min }$ to prevent cutter interference, and a compact construction cannot be achieved with large $z$ values. Moreover, the curvature radius of the tooth profile and the tooth thickness of the pinion at the root are less than those of the gear. Therefore, the strength of the pinion is much lower than that of the gear. 
Addendum modification is employed to improve the performance of gears. Corrected gears are those with addendum modification, and the modified value is expressed by the distance between the pitch line and the centerline of the cutter. The distance is defined as $x m$, where $x$ is addendum modification coefficient and $m$ is also the module of the gear. If the cutter is set away from the position for cutting a standard gear, then $x$ and the modification are considered positive. Otherwise, $x$ and the modification are negative.

In traditional theories, the modification distance $x m$ of the rack-shaped cutter should be calculated to prevent cutting, as shown in Fig. 1. The condition for preventing the undercutting of the root is $x m \geq\left(h_{a}^{*} m-N_{l} G\right)$. The result is

$$
x \geq h_{a^{-}}^{*} \frac{z \sin ^{2} \alpha}{2}
$$

from which the minimal modification coefficient $x_{\min }$ of the spur gear can be derived using Eq. (3):

$$
x_{\min }=\frac{h_{a}^{*}\left(z_{\min }-z\right)}{z_{\min }} .
$$

Evidently, $x_{\min }>0$ if $z<z_{\min }$. When $z>z_{\min }$, the gear can be negatively modified as $x_{\min }<0$.

\section{2 $x_{\min }$ of the involute gear considering the effect of bottom clearance $c$}

The bottom clearance $c$ is also ignored in the deduction process of $x_{\min }$ in traditional theories. However, $c$ should be considered in practice, as shown in Fig. 4. Then, the condition for preventing undercutting of the root is $x m \geq\left(h_{a}^{*} m+c^{*} m-N_{1} \mathrm{G}\right)$. The result is

$$
x \geq\left(h_{a}^{*}+c^{*}-\frac{z \sin ^{2} \alpha}{2}\right),
$$

from which the minimal modification coefficient $x_{\min }$ of the spur gear can be derived using Eq. (8),

$$
x_{\min }=\frac{\left(h_{a}^{*}+\mathrm{c}^{*}\right)\left(z_{\min }-z\right)}{z_{\min }} .
$$

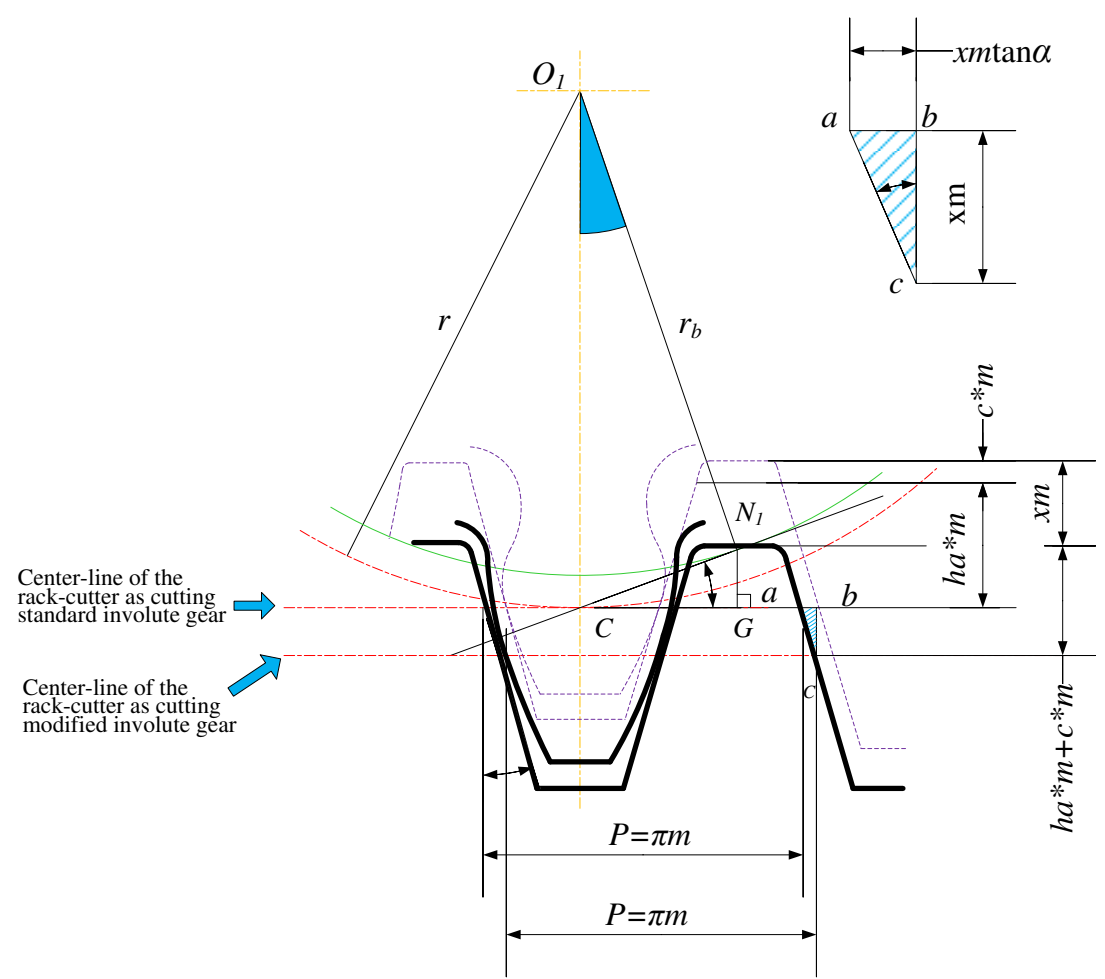

Fig. 4 Undercut and modification of standard involute gear in practice 
The minimum teeth numbers for the spur, helical, and bevel gears in practice are provided in Sections 3.1.1 and 3.1.2, and the results are shown in Table 1. The minimum modification coefficient can be calculated by substituting $h_{a}^{*}=1$ and $c^{*}=0.25$ (for bevel gear, $c^{*}=0.2$ ) and inserting the results in column $\square$ of Table 2 into Eq. (12), and the results are shown in column $\square$.

Table $2 x_{\min }$ of standard involute gears without undercutting

\begin{tabular}{|l|c|c|c|}
\hline Standard involute gears & Manufactured by rack-cutter & Required tooth number & $x_{\min }$ \\
\hline Spur gears & $z_{\min }=22$ & $z=12 / 17$ & $x_{\min }=0.57 / 0.28$ \\
\hline Helical gears & $z_{\min }=20\left(\beta=15^{\circ}\right)$ & $z=12 / 17\left(\beta=15^{\circ}\right)$ & $x_{\min }=0.5 / 0.186$ \\
\hline Straight bevel gears & $z_{\min }=18\left(\delta=35^{\circ}\right)$ & $z=12 / 17\left(\delta=35^{\circ}\right)$ & $x_{\min }=0.4 / 0.07$ \\
\hline
\end{tabular}

\section{Numerical simulation of the undercutting of standard involute spur gear}

A specialized computer software is used to simulate and analyze the cutter interference of involute spur gears manufactured by a rack cutter, to illustrate the undercutting phenomenon in the traditional theory and in the research in this paper. In the following simulations, the values of used parameters are set as $h_{a}^{*}=1, c^{*}=0.25, \alpha=20^{\circ}, m=4$, and width of gear $B=20 \mathrm{~mm}$.

\subsection{Simulation of spur gear with $\mathrm{z}=10$}

As mentioned in the main text, undercutting at the pinion root may affect the load distribution and meshing character amongst pairs of involute gear teeth in simultaneous contact. Hence, the undercutting phenomenon of standard involute spur gear with $\mathrm{z}=10$ is simulated as follows.

Figs. 5 (A) and (B) indicate that the top of the rack-cutter enters the profile of the gear and some parts of the involute profile near the root portion are removed. Apparently, a serious undercut has already occurred in its manufacturing process when $z=10$. Using Eq. (10), the minimum modification coefficient for spur gear of $\mathrm{z}=10$ in conventional theories can be calculated as $x_{\min }=0.41$; the corresponding drawings are shown in Figs. 5 (C) and (D). After considering the modified $x_{\min }=0.68$ derived from Eq. (12) into the manufacturing process of spur gear with $z=10$, the corrected spur gear is simulated on the basis of the software, as shown in Figs. 5 (E) and (F). Comparison of the three types of situations in Fig. 5 shows the following: 1) heavy undercutting appears in the gear without modification; 2) undercutting occurs in the spur gear manufactured with $x_{\min }$ calculated following the conventional theory Eq. $\left.(10) ; 3\right)$ no cutter interference emerges when $x_{\min }$ is calculated based on Eq. (12) and when the effect of bottom clearance is considered. Therefore, the bottom clearance $c$ of the rack-cutter must be considered during the manufacturing of involute gears, and the $c$ is a crucial factor for the studies on undercutting phenomenon and minimum teeth number of standard involute gears.
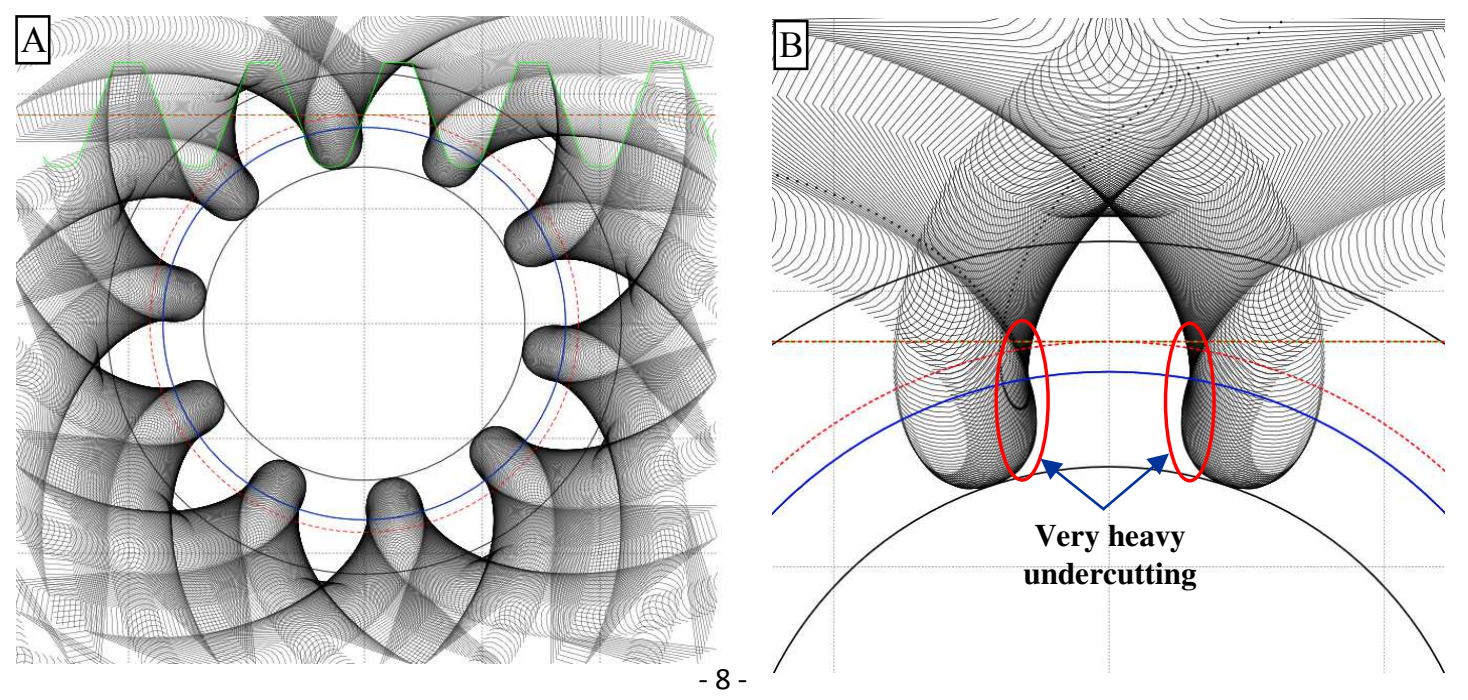

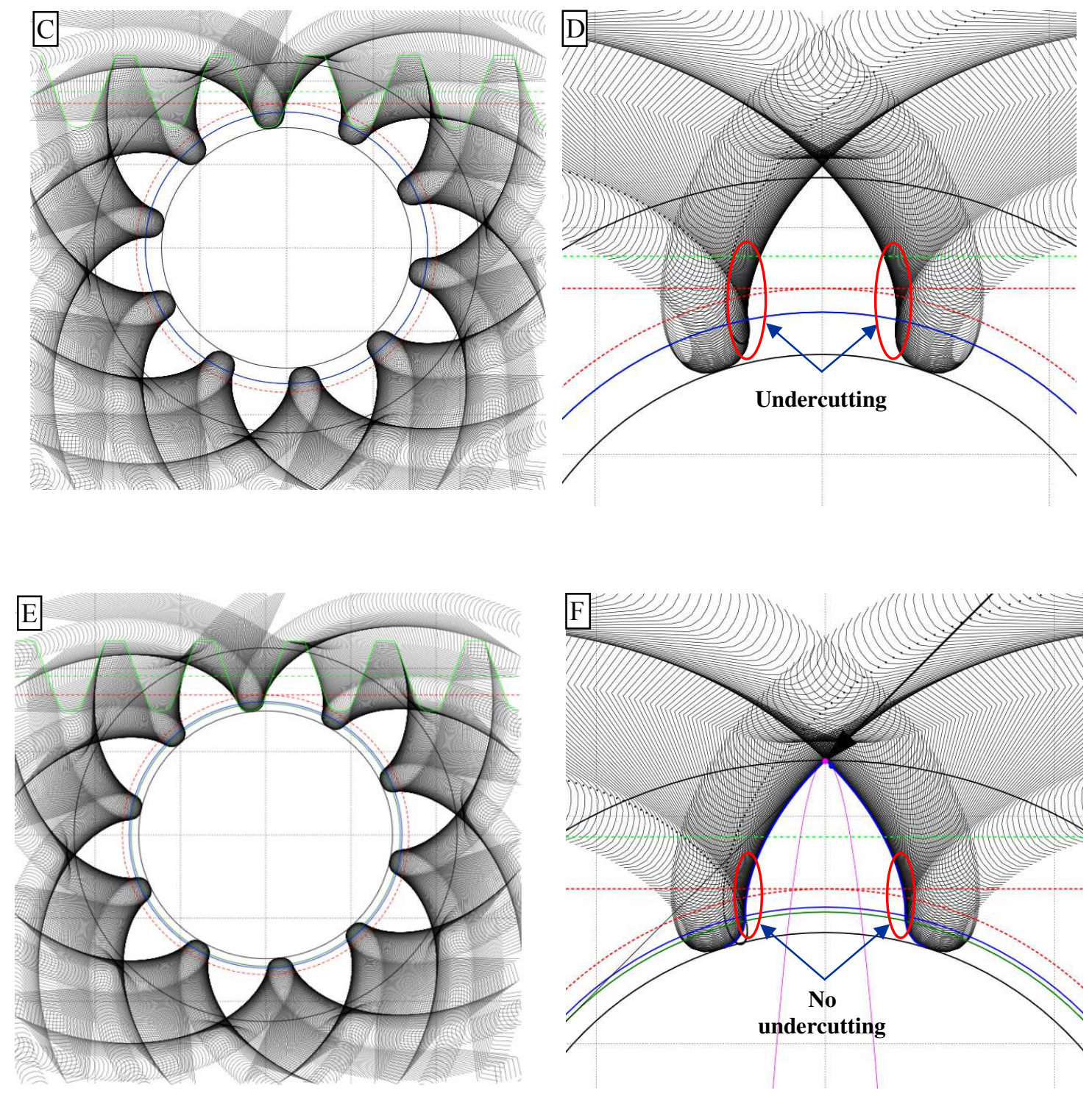

Fig. 5 Representative simulated standard involute spur gear with $\mathbf{z = 1 0}$. A) Standard involute spur gear of $\mathrm{z}=10$ without modification. B) Enlarged tooth profile of $\mathrm{z}=10$ without modification. C) $x_{\min }=0.41$. D) Enlarged tooth profile corrected with $x_{\min }=0.41$. E) Standard involute spur gears of $\mathrm{z}=10$ with $x_{\min }=0.68$. F) Enlarged tooth profile of $\mathrm{z}=10$ with $x_{\min }=0.68$.

\subsection{Simulation of spur gear with $\mathrm{z}=12$}

Figs. 6 (A) and (B) show that the rack-cutter enters the profile of the gear and some parts of the involute profile near the root portion are removed for the spur gear of $z=12$ without correction. Serious undercutting also occurs. Using Eq. (10), the minimum modification coefficient for spur gear of $z=12$ in conventional theories can be calculated as $x_{\min }=0.29$; the corresponding drawings are shown in Figs. 6 (C) and (D). After considering the modified $x_{\min }=0.57$ derived from Eq. (12) into the manufacturing process of spur gear with $z=12$, the corrected spur gear is simulated based the software, as shown in Figs. 6 (E) and (F). Comparison of the three types of situations, demonstrates the following: 1) heavy undercutting is observed in the gear without modification; 2 ) slight undercutting occurs in the spur gear manufactured with $x_{\min }$ calculated following the conventional theory, Eq. (10); 3) no cutter interference emerges when $x_{\min }$ is calculated based on 
Eq. (12). Thus, these results again prove that the bottom clearance $c$ of the rack-cutter must be considered during the manufacturing of involute spur gears.
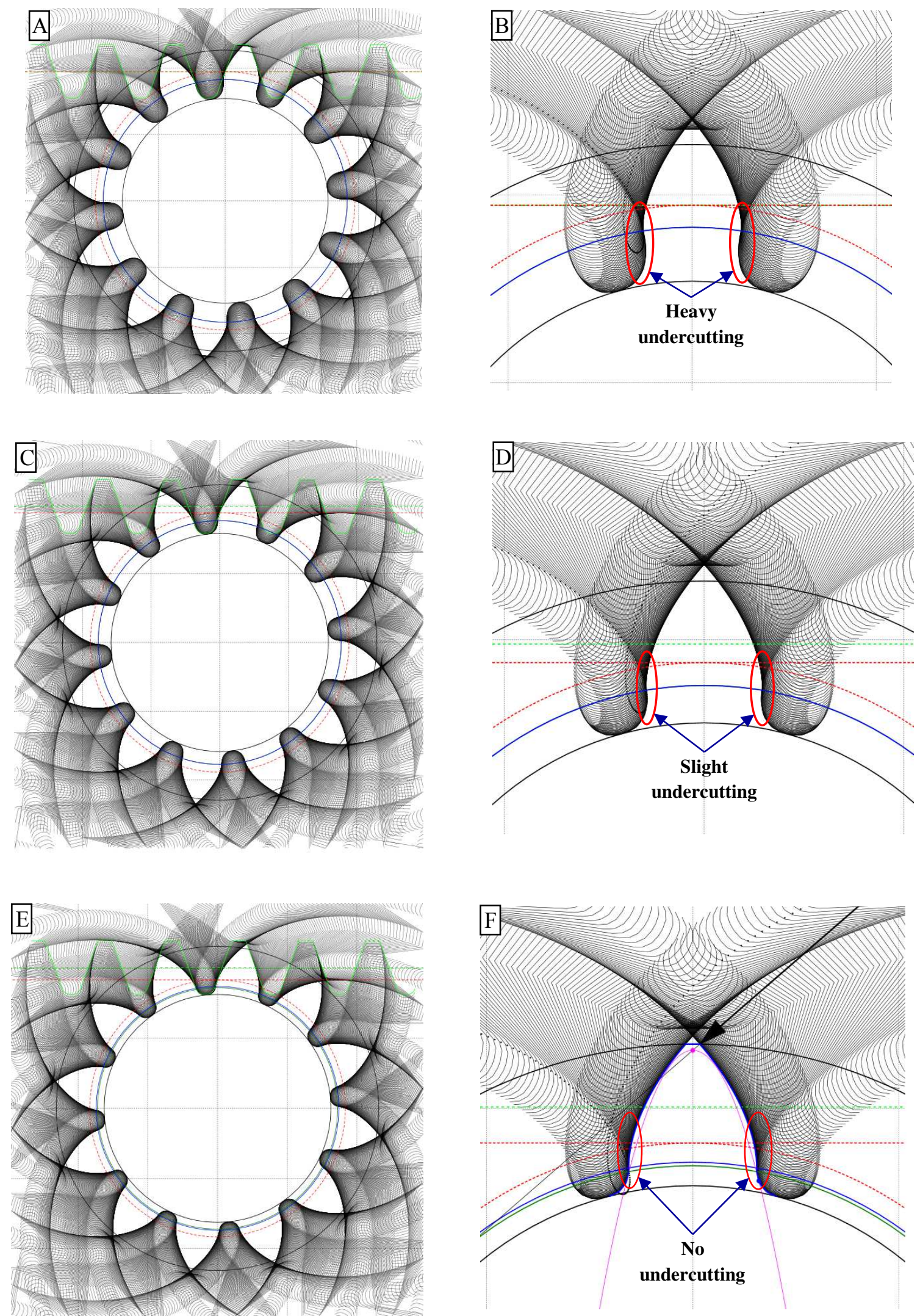
Fig. 6 Representative simulated manufacturing drawing of spur gear with $\mathbf{z}=12$. A) $x_{\min }=0$. B) Enlarged tooth profile without modification. C) $x_{\min }=0.29$. D) Enlarged tooth profile corrected with $x_{\min }=0.29$. E) $x_{\min }=0.57$. F) Enlarged tooth profile corrected with $x_{\min }=0.57$.

\subsection{Simulation of spur gear with $\mathrm{z}=17$}

The drawing of spur gear with $z=17$ in conventional theory is simulated as shown in Fig.7. Meanwhile, Fig.7 (B) indicates that the top of the rack-cutter enters the profile of the gear and some parts of the involute profile near the root portion are removed. Cutter interference has already occurred in its manufacturing process when $z=17$. Using Eq. (12), the $x_{\min }$ of standard involute spur gear with $z=17$ can be obtained as 0.28 . The simulation of corrected spur gear of $z=17$ with $x_{\min }=0.28$ is shown in Figs.7 (C) and (D). The simulation results showed that no cutter interference occurs in the corrected spur gear of $z=17$, thereby proving the accuracy of the research in Section 4.2.
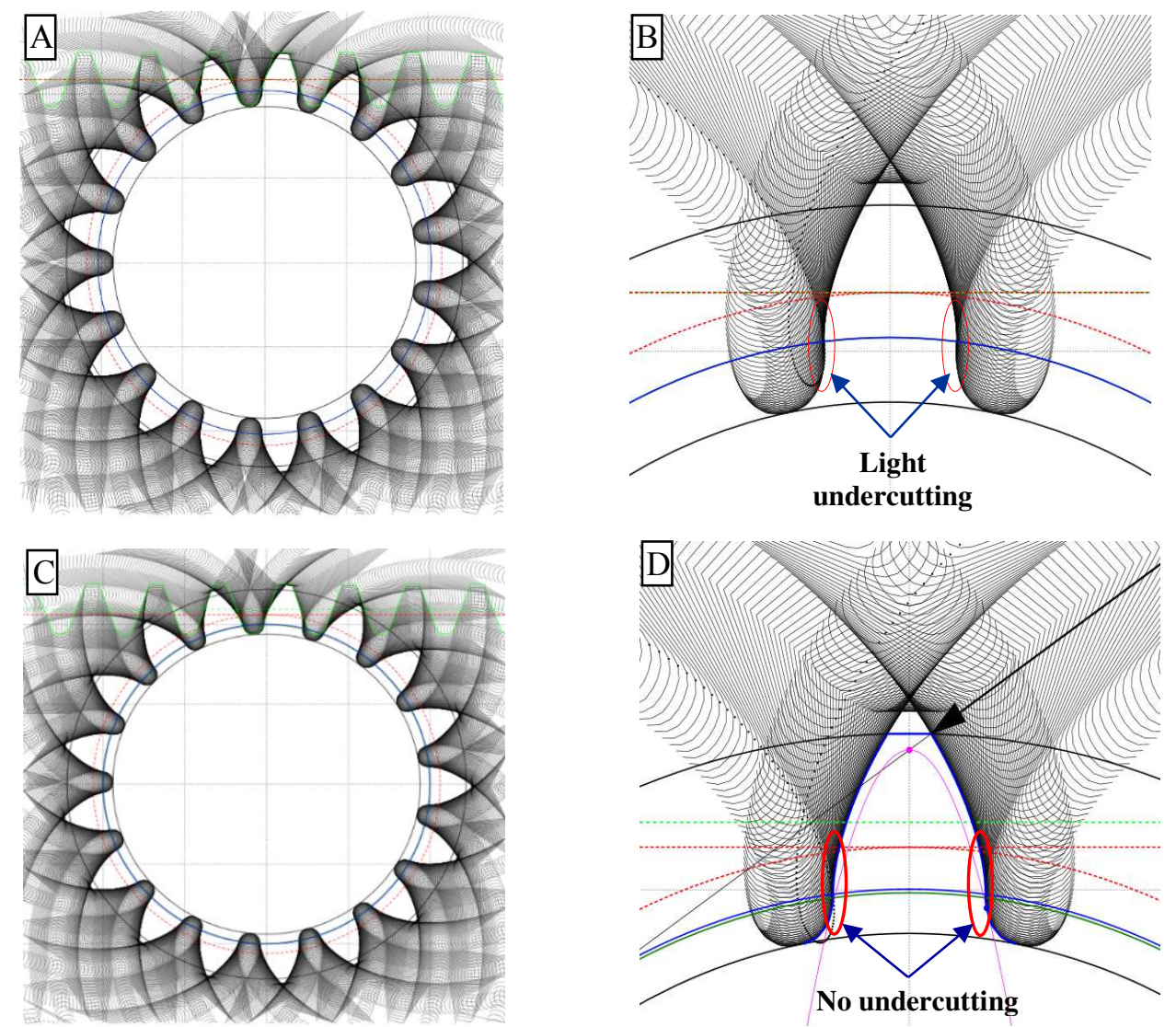

Fig.7 Representative simulated manufacturing drawing of $z=17$. A) Diagram of $z=17$ in conventional theory. B) Original tooth profile. C) Diagram of $\mathrm{z}=17$ with $x_{\min }=0.28$ (considering the effect of bottom clearance). D) Enlarged corrected tooth profile.

\subsection{Simulation of spur gear with $\mathrm{z}=22$}

Fig. 8 shows the simulated manufacturing processes of $z=22$. As shown in Figs. 8 (A) and (B), the top of the rack-cutter has not entered the profile of the gear and the involute profile is fully manufactured. In other words, cutter interference will not occur when the tooth number of spur gear $z=22$; such a result is consistent with the research result in Section 3.1.1. 

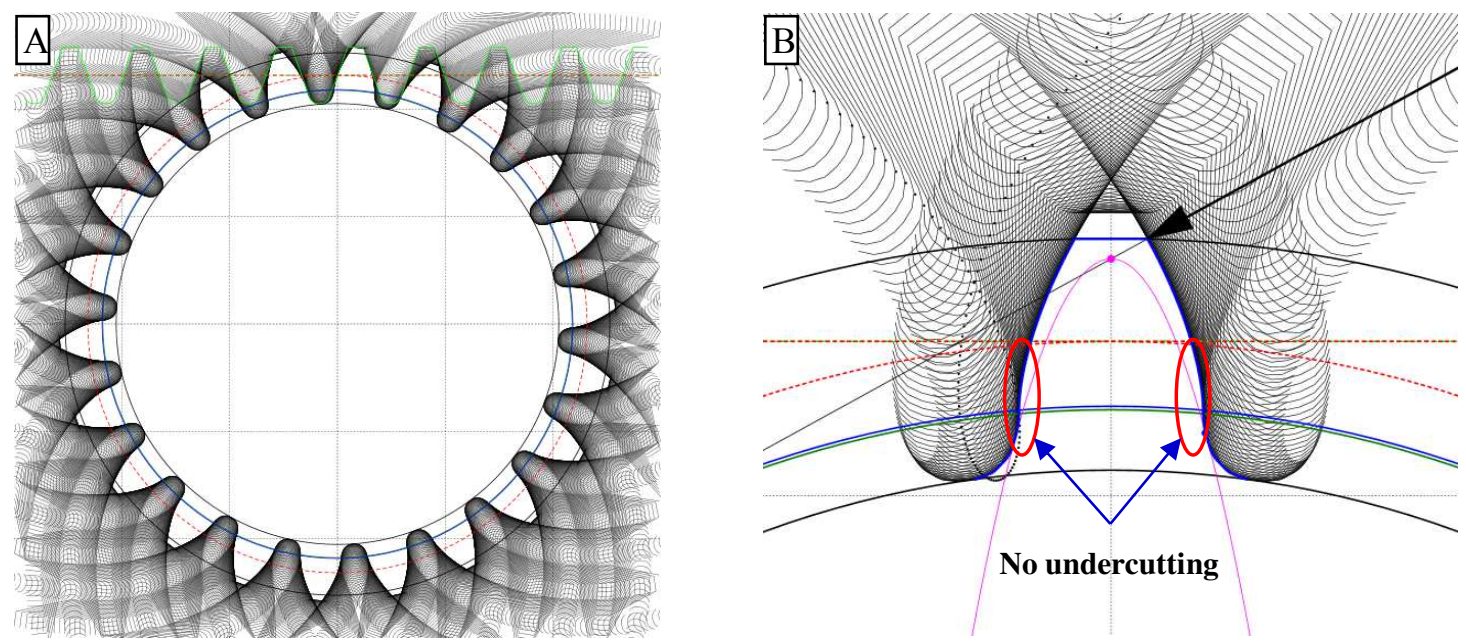

Fig. 8 Representative simulated manufacturing drawing of $z=22$. A) Diagram of $z=22$ in conventional theory; B) Enlarged tooth profile.

\section{Experiment of undercutting phenomenon of standard involute spur gear}

The undercutting of gear with fewer teeth is directly explored by conducting machining experiments for the standard involute spur gears with teeth numbers of 10, 12, 17, and 22. Support was provided by Kunming Machine Tool Co., Ltd. of Shenyang Machine Tool Group.

\subsection{Material}

For convenience of gear machining and subsequent antirust processing, aluminium alloy bar model 6061-T651 is selected as the raw material for gear machining. Magnesium and silicon are the main alloy elements, and that form the Mg2Si phase. Via pre-tension technology processing, the bar processes good quality, such as excellent processing performance, fine welding characteristics and electroplating, excellent corrosion resistance, high toughness and high resistance to deformation, dense material without defects, and easy polishing.

\subsection{Processing equipment}

The Y3180H General-purpose Gear Hobbing Machine manufactured by Chongqing Machine Tool (Group) Co., Ltd. is adopted in the manufacturing process of gears. The model is applicable to cut spur and helical gears, worm wheels, sprockets, and short spline shafts in jobbing, small, or batch production. The maximum allowable machining diameter of the workpiece is $800 \mathrm{~mm}$, and the maximum allowed machining module is $8 \mathrm{~mm}$. The machine is characterized by good rigidity, high working accuracy, easy operation, and simple setup procedure. Either conventional or climb method can be used in the machine.

\subsection{Manufactured gears}

In testing and verifying the undercutting phenomenon in the gear machining process, five types of standard involute spur gears with teeth numbers $z=10,12,14,17$ and 22 are manufactured, and the addendum modifications are considered in the manufacturing process. The detailed parameters of the gears are shown in Table 3. 
Table 3 Parameters of the involute gears to be processed

\begin{tabular}{|c|c|c|c|c|c|l|}
\hline No. Item & $\mathrm{z}$ & $\mathrm{m}$ & $x_{\min }$ & $h_{a}^{*}$ & $c^{*}$ & \multicolumn{1}{|c|}{ Note } \\
\hline \multirow{3}{*}{1} & 10 & 4 & 0 & 1 & 0.25 & Very heavy undercutting \\
\cline { 2 - 7 } & 10 & 4 & 0.68 & 1 & 0.25 & Without undercutting \\
\hline \multirow{2}{*}{2} & 12 & 4 & 0 & 1 & 0.25 & Heavy undercutting \\
\cline { 2 - 7 } & 12 & 4 & 0.57 & 1 & 0.25 & Without undercutting \\
\hline \multirow{2}{*}{3} & 17 & 4 & 0 & 1 & 0.25 & Slight undercutting \\
\cline { 2 - 8 } & 17 & 4 & 0.28 & 1 & 0.25 & Without undercutting \\
\hline \multirow{2}{*}{4} & 22 & 4 & 0 & 1 & 0.25 & Without undercutting \\
\hline
\end{tabular}

\subsubsection{Standard involute spur gears of $\mathrm{z}=10$}

The tooth profiles of $z=10$ standard involute spur gears with and without modification are intuitively investigated by comparing the two processed gears, as shown in Fig. 9. Figs. 9 (A) and (B) indicate that a serious teeth profile changes of $z=10$ without modification occur close to the root, and the meshing conditions of gears are abnormal. The profiles of two gears in Figs.9 (A) and (C) are enlarged and then shown in Figs. 9 (D) and (E) to further observe the gear tooth profile changes of $z=10$ with and without modification. Black lines in the two figures marked the standard involute tooth profiles. Clearly, part of the gear tooth profile of $z=10$ without modification is cut off (yellow shading) from Fig.9 (D), indicating that a very heavy undercutting occurs and the abnormal meshing of gear. Fig. 9 (E) shows that the gear tooth profile of $z=10$ with modification coefficient of $x_{\min }=0.68$ presents no undercut, and the entire involute line is sufficiently smooth such that gears can mesh regularly.
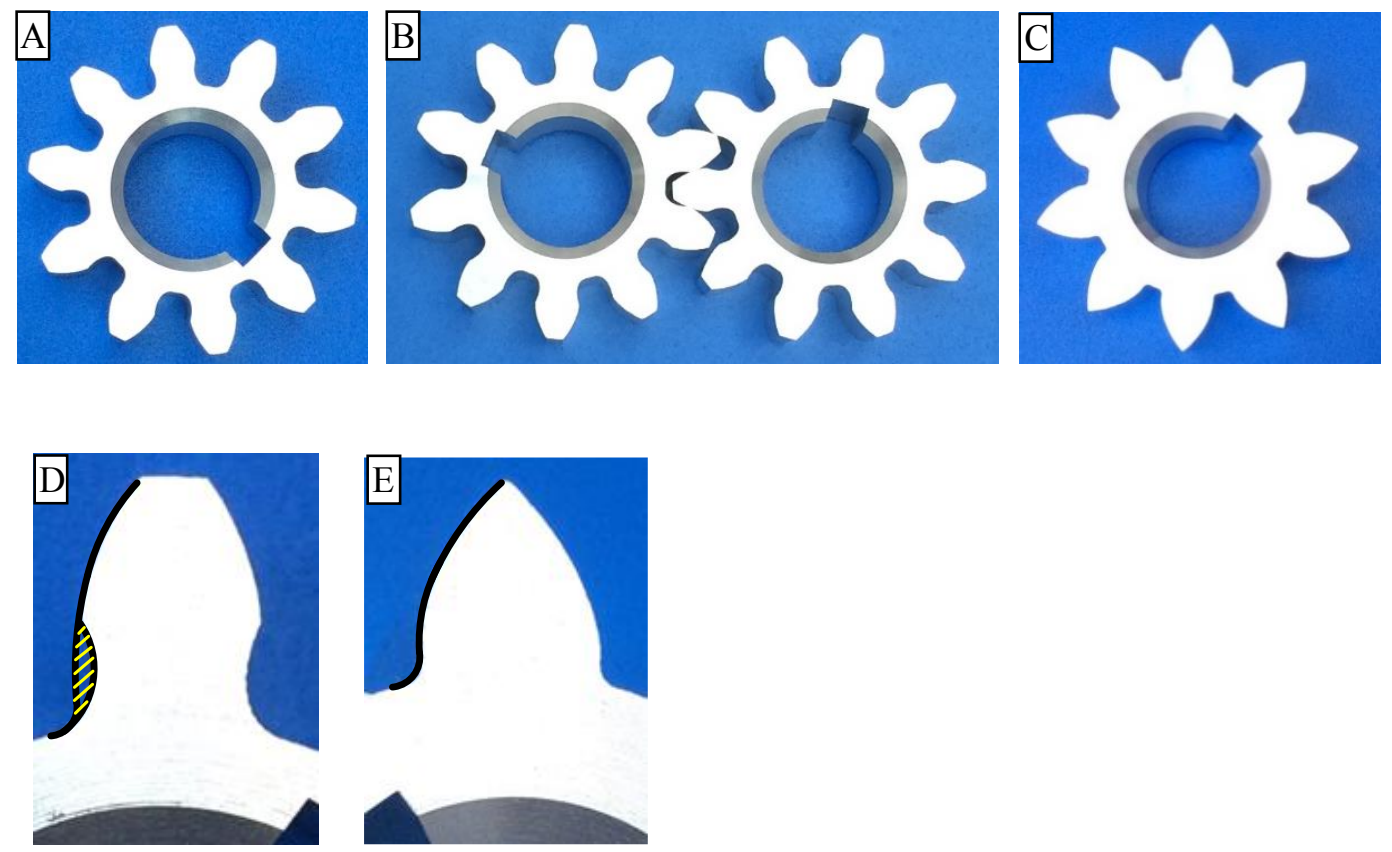

Fig.9 Representative manufactured standard involute spur gear with $z=10$. A) Standard involute spur gear of $z=10$ without modification. B) Meshing diagram of two standard involute spur gears of $z=10$ without modification. C) Standard involute spur gears of $z=10$ with $x_{\min }=0.68$. D) Enlarged tooth profile without modification. E) Enlarged tooth profile with modification.

\subsubsection{Standard involute spur gears of $z=12$}

As previously mentioned, the tooth profiles of $z=12$ standard involute spur gears with and without 
modification are visually examined by comparing the two processed gears, as shown in Fig.10. Figs. 10 (A) and (B) respectively show that a serious teeth profile changes of $z=12$ without modification occur close to the root and the meshing conditions of gears are abnormal. The profiles of two gears in Figs.10 (A) and (C) are enlarged and then shown in Figs. 10 (D) and (E) to further observe the gear tooth profile changes of $z=12$ with and without modification. Fig. 10 (D) shows that part of the gear tooth profile of $z=12$ without modification is cut off (yellow shading), indicating the occurrence of heavy undercut phenomenon and the abnormal meshing of gear. Fig. 10 (E) shows that the gear tooth profile of $z=12$ with modification coefficient of $x_{\min }=0.57$ exhibits no undercut, and the entire involute line is sufficiently smooth such that gears can mesh regularly.
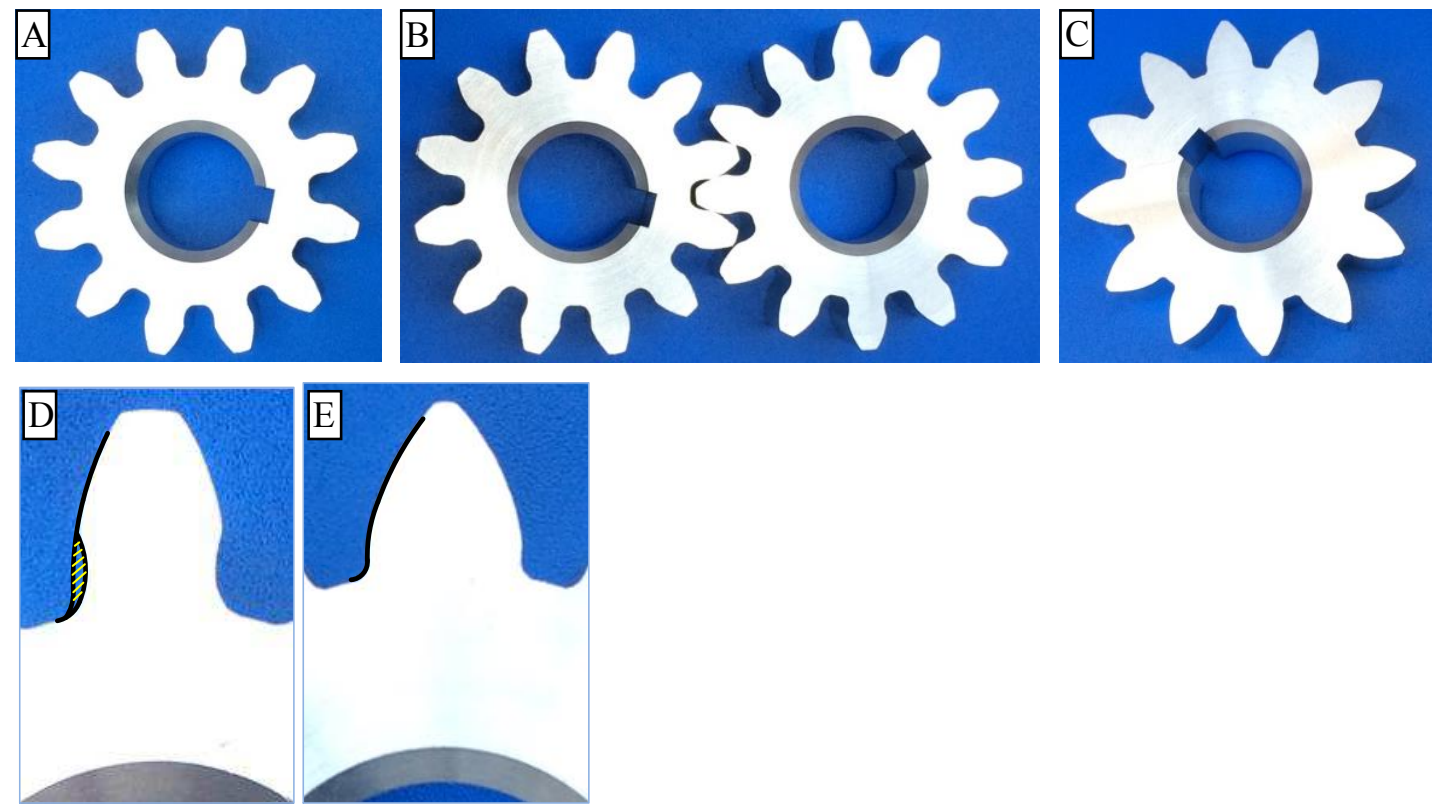

Fig. 10 Representative manufactured standard involute spur gear with $z=12$. A) Standard involute spur gear of $z=12$ without modification. B) Meshing diagram of two standard involute spur gears of $z=12$ without modification. C) Standard involute spur gears of $z=12$ with $x_{\min }=0.57$. D) Enlarged tooth profile without modification. E) Enlarged tooth profile with modification.

\subsubsection{Standard involute spur gears of $z=17$}

For standard involute spur gears, the noninterference minimum tooth of the meshing gear with rack is $z_{\min }=17$ in traditional theory when the pressure angle $\alpha=20^{\circ}$ and $h_{a}^{*}=1$. However, the current study concludes that the root cutting will continue to occur when $z=17$. The teeth changes of standard involute spur gears of $z=17$ with and without modification are directly determined by comparing the two processed gears, as shown in Fig 11. Figs. 11 (A) and (B) indicate that nearly nothing has occurred close to the root in serious teeth profile changes of $z=17$ without modification. The profiles of two gears in Figs.11 (A) and (C) are enlarged and then shown in Figs. (D) and (E) to further observe the gear tooth profile changes of $z=17$ with and without modification. Fig. 11 (D) shows that a tiny part of the gear tooth profile of $\mathrm{z}=17$ without modification is cut off (yellow shading), indicating the occurrence of a slight undercut phenomenon and the abnormal meshing of gear. Fig. 11 (E) shows that the gear tooth profile of $z=17$ with modification coefficient of $x_{\min }=0.28$ exhibit no undercutting, and the entire involute line is sufficiently smooth such that gears can mesh regularly.
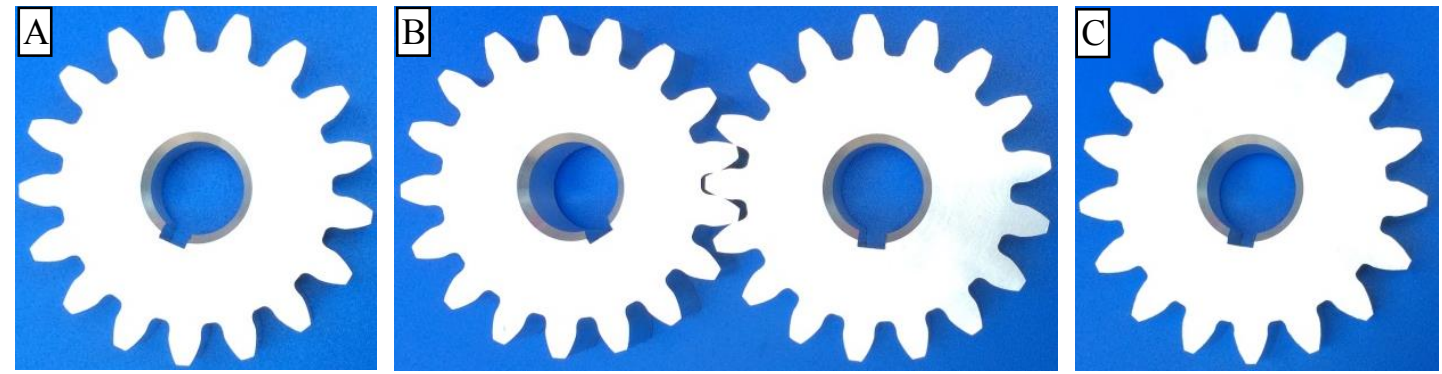

$-14-$ 


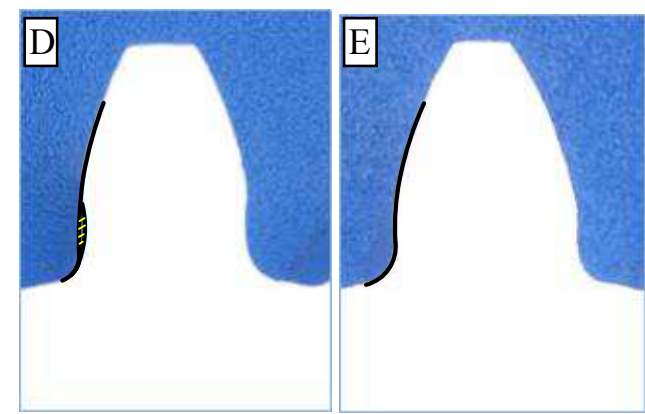

Fig. 11 Diagrams of manufactured standard involute spur gear with $\boldsymbol{z}=\mathbf{1 7}$. A) Standard involute spur gear of $z=17$ without modification. B) Meshing diagram of two standard involute spur gears of $\mathrm{z}=14$ without modification. C) Standard involute spur gears of $\mathrm{z}=12$ with $x_{\min }=0.28$. D) Enlarged tooth profile without modification. E) Enlarged tooth profile with modification.

\subsubsection{Involute spur gears of $\mathrm{z}=22$}

The overall results show that the correct noninterference minimum tooth of the meshing standard involute spur gear with rack is $z_{\mathrm{min}}=22$. The tooth profile of a correspondingly manufactured gear is analyzed, shown in Fig.12. Figs. 12 (A) and (B) show that no changes occur in the tooth profile of $z=22$ without modification. To further observe the gear tooth profile changes, the profiles of gear without modification in Fig.12 (A) are enlarged and then shown in Fig.12 (C). No changes clearly occur in the gear tooth profile of $z=22$ without modification, indicating no interference in the gear processing. In addition, the entire involute line of tooth is sufficiently smooth such that gears can mesh regularly. These results are consistent with the theoretical and numerical results.

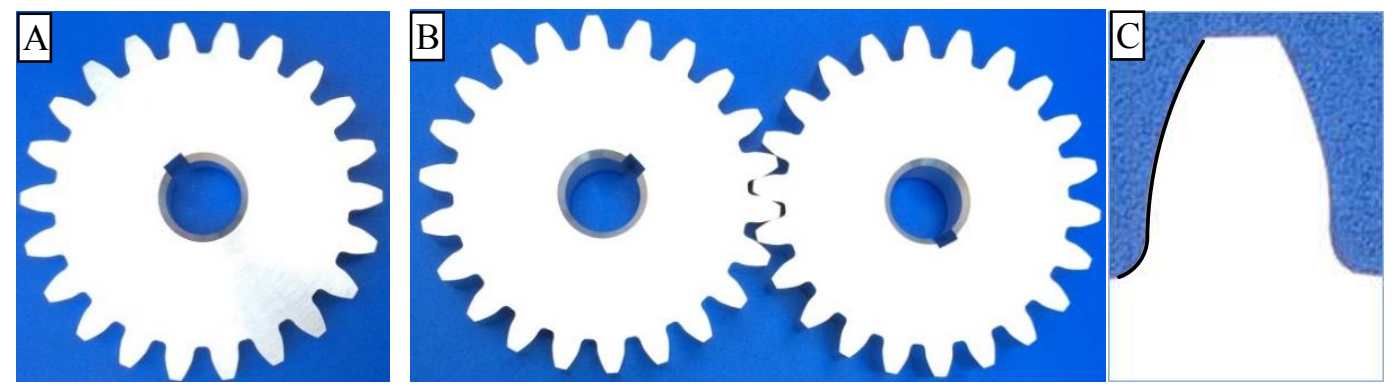

Fig. 12 Representative manufactured standard involute spur gear with $z=22$. A) Standard involute spur gear of $z=22$ without modification. B) Meshing figure of two standard involute spur gears of $z=22$ without modification. C) Enlarged tooth profile without modification.

\section{Conclusions}

The gear tooth undercutting issues are important in gear design and manufacture. In many textbooks on mechanical engineering, rack has been mistakenly regarded as rack cutter. Thus the minimum teeth number without undercutting has been deduced, causing the misunderstanding of the undercut phenomenon for many years. Meanwhile, this misconception is continually imparted to tens of thousands of students in universities yearly. In the present study, the theoretical analysis and calculation of the $z_{\min }$ of standard involute gears, were performed, where the rack in conventional theories was changed into the rack cutter. The calculation values showed that the minimum teeth numbers of the three most frequently used kinds of involute gears should be large (as Table1). The results are strikingly different from those of traditional theories, which necessitate a theoretical conference on involute gear manufacturing.

For standard involute gears, the number of teeth should not be less than $z_{\min }$ to prevent cutter interference, and a more compact construction cannot be achieved with large $z$ values. Moreover, the curvature radii of the tooth profile and the tooth thickness of the pinion at the root are less than those of the gear. Addendum modification is usually employed to satisfy the fewer teeth requirement and improve the performance of gears. In the present study, the $x_{\min }$ of the standard involute gear 
in conventional theories and the effect of the bottom clearance were analysed. The $x_{\min }$ of the three kinds of standard involute gears was calculated on basis of deduction formula (12). The results showed that the $x_{\min }$ increased when the bottom clearance was considered.

The spur gear was taken as an example, where the minimum teeth number and the modification coefficient in conventional theory and those in the current research were simulated to visually illustrate the theoretical research on the $z_{\min }$ and $x_{\min }$ of standard involute gears. Meanwhile, the experiments were developed correspondingly. The simulation and experiment results proved the validity of the theoretical analysis. Based on the theoretical analysis and simulations, the bottom clearance $c$ of the rack-shaped cutter must be considered during the manufacturing of involute gears, which is a crucial factor for the studies on the undercutting phenomenon and the minimum teeth number of involute gears.

\section{Declarations}

\section{1) Availability of data and materials}

All data generated or analyzed during this study are included in the article.

\section{2) Competing interests}

No conflict of interest exits in the submission of this manuscript, and manuscript is approved by all authors for publication.

\section{3) Funding}

The authors express sincere thanks to the Kunming University of Science and Technology for financing this research within the project "Key teaching reform project of the mechanical design and principles in 2017', under the label 130310963119.

\section{4) Authors' contributions}

Hongshen Zhang: Methodology, Editing Data, Writing- Original draft preparation.

Jianing He: Conceptualization, Editing.

\section{5) Acknowledgements}

The author expresses sincere thanks to the Italian mechanical engineer Angelo Bertocchi for his help in simulation (website: www.me-bac.com), and sincere thanks to the Kunming Machine Tool Co., Ltd, Shenyang Machine Tool Group for the help in the process of machining gears.

\section{References}

[1]. Alessio Artoni. A methodology for simulation-based, multiobjective gear design optimization. Mechanism and Machine Theory, 2019.133: 95-111.

[2]. Wen Q, Du Q, Zhai X. An analytical method for calculating the tooth surface contact stress of spur gears with tip relief. Int J Mech Sci, 2019, 151: 170-180.

[3]. Patil S S, Karuppanan S, Atanasovska I, et al. Contact stress analysis of helical gear pairs, including frictional coefficients. Int J Mech Sci, 2014, 85: 205-211.

[4]. Armillotta A. Tolerance analysis of gear trains by static analogy. Mechanism and Machine Theory, 2019, 135: 65-80.

[5]. Bozca M. Transmission error model-based optimisation of the geometric design parameters of an automotive transmission gearbox to reduce gear-rattle noise. Applied Acoustics, 2018, 130: 247-259.

[6]. Chowdhury S, Yedavalli R K. Vibration of high speed helical geared shaft systems mounted on rigid bearings. Int J Mech Sci, 2018, 142: 176-190. 
[7]. Li W, Zhai P, Tian J, et al. Thermal analysis of helical gear transmission system considering machining and installation error. Int J Mech Sci, 2018, 149: 1-17.

[8]. Robert L M, Mott P E. Machine elements in mechanical design (Prentice Hall, Lebanon, IN, ed. 4, 2003).

[9]. Pedrero J I, Pleguezuelos M, Muñoz M. Contact stress calculation of undercut spur and helical gear teeth. Mech Mach Theory, 2011, 11: 1633-1646.

[10].Litvin F L, Fuentes A. Gear Geometry and Applied Theory (Cambridge University Press, Cambridge, ed. 2, 2004).

[11]. Chao L C, Tsay C B. Tooth flank, undercutting and tooth pointing of spherical gears. Mech Mach Theory, 2011, 4, 534-543.

[12]. Ye Z H, Zhang W, Huang Q H, Chen C M. Simple explicit formulae for calculating limit dimensions to avoid undercutting in the rotor of a cycloid rotor pump. Mech Mach Theory, 2006, 4: 405-414.

[13]. Chen Z X. Proof of the undercutting phenomenon for an involute tooth profile on a cylindrical gear. Mech Mach Theory, 1992, 1: 93-95.

[14]. Norton R L. Design of machinery: an introduction to the synthesis and analysis of mechanisms and machines (McGraw-Hill Professional, US, ed. 2, 2004).

[15].Litvin F L. Theory of Gearing (Nauka, Moscow, 1968 (In Russian)).

[16].Colbourne J R. "Gear cutting I Spur Gears" in The Geometry of Involute Gears(SpringerVerlag, New York, 1987), p.110-140.

[17].Svahn M. The Undercut Criterion of Pinion Shaper Cutters: And an Improvement by Modifying the Basic Rack Profile. J. Manu. Sci. Eng., 2016, 1: 011011.

[18]. Semenchenko I I, (Trans. Li D H, Hu M T). Gear Cutter (Mechanical Industry Press, Beijing, CN, 1958), p. 32-33. (In Chinese)

[19].Litvin F L, (Trans. Ding C). Principles of Gear Connection (Shanghai Scientific and Technical Publishers, Shanghai, CN 1964), p. 77-79. (In Chinese)

[20]. Spotts M F, Design of machine elements (Prentice hall, Englewood Cliffs, NJ, ed. 6, 1985), p. 492-493.

[21]. Spotts M F, Shoup T E, Hornberger L E. Design of machine elements (Pearson Education, New York, ed. 8, 2003).

[22]. Shigley J E, Mischke C. Mechanical Engineering Design (McGraw-Hill, New York, ed. 6, 2001), p. 846-847.

[23].Houghton P S, Gears; spur, helical, bevel, internal, epicyclic and worm (Technical Press, London, ed. 3, 1970).

[24]. Dudley D W, Gear Handbook (McGraw-Hill Book Company, New York, 1962), p. 5-15.

[25]. Mott R L, Machine Elements in Mechanical Design (Prentice hall, New Jersey, ed. 2, 1963), p. 392-393.

[26].Mott R L, Machine Elements in Mechanical Design (Prentice Hall, Lebanon, Indiana, USA, ed. 5 2013).

[27].Budynas R, Nisbett K, Mechanical Engineering Design (McGraw-Hill Education, Columbus, OH, ed. 10, 2014).

[28]. Alipiev O, Antonov S, Grozeva T. Generalized model of undercutting of involute spur gears generated by rack-cutters. Mech Mach Theory, 2013, 64: 39-52.

[29].Pu L G, Ji M G. Machine Design (Higher Education Press, Beijing, China, ed. 9, 2013(In Chinese)).

[30].Sun H. Principle of Mechanics (Higher Education Press, Beijing, China, ed. 10, 2013(In Chinese)).

[31]. Ye Z H, Lan Z H, Smith M R. Mechanisms and machine theory (Higher Education Press, Beijing, China, 2001).

[32].He J N, Zhang W, Zhang H B, Ma W X, Chen S, Li Q, Gao Y. Study on minimum teeth without undercutting of standard involute gears. Advanced Materials Research. Trans Tech Publications, 2011, 199: 329-336.

[33].He J N, Gao Y, Zhang H B, Zhang C, Deng, X L. Simulation Research on Undercutting Properties of Involute Gears Based on VB. Advanced Materials Research. Trans Tech Publications, 2013, 655: 408-411.

[34].He J N, Gao Y, Zhang H B, Zhang C, Deng, X L. Study on Avoiding Undercutting of Stub Tooth Involute Gear with 22.5 Degree Pressure Angle. Advanced Materials Research. Trans. 
Tech. Publications, 213, 655: 592-595.

[35]. Gao Y, He J N, Zhang H B, Zhang W, Zhang C. Study on Minimum Teeth without Undercutting of the Spur Involute Gears with $22.5^{\circ}$ and $25^{\circ}$ Pressure Angle Based on VB. Paper presented at the Computer Science and Electronics Engineering (ICCSEE), 2012 International Conference on. IEEE, Hangzhou, CN, 23-25, March, 2012.

[36].Zhang C, He J N, Gao Y, Deng X L. Study on Minimum Teeth without Undercutting of Involute Gears with 14.5 Degree Pressure Angle. Key Engineering Materials. Trans Tech Publications, 2013, 544: 497-501.

[37].Xiao J, Deng X L, He J N, Ma W X, Li Y, Li J S. Simulation and Analysis about Different Pressure Angle in Involute Gears Based on Neural Network. Applied Mechanics and Materials. Trans Tech Publications, 2014, 540: 88-91.

[38].Tseng R T, Tsay C B. Mathematical model and undercutting of cylindrical gears with curvilinear shaped teeth. Mechanism and Machine Theory, 2001, 36(11-12): 1189-1202.

[39].Mimmi G C, Pennacchi P E. Non-undercutting conditions in internal gears. Mechanism and Machine Theory, 2000, 35(4): 477-490.

[40]. Chiang C J, Fong $\mathrm{Z} \mathrm{H}$. Undercutting and interference for thread form grinding with a tilt angle. Mechanism and Machine Theory, 2009, 44(11): 2066-2078. 


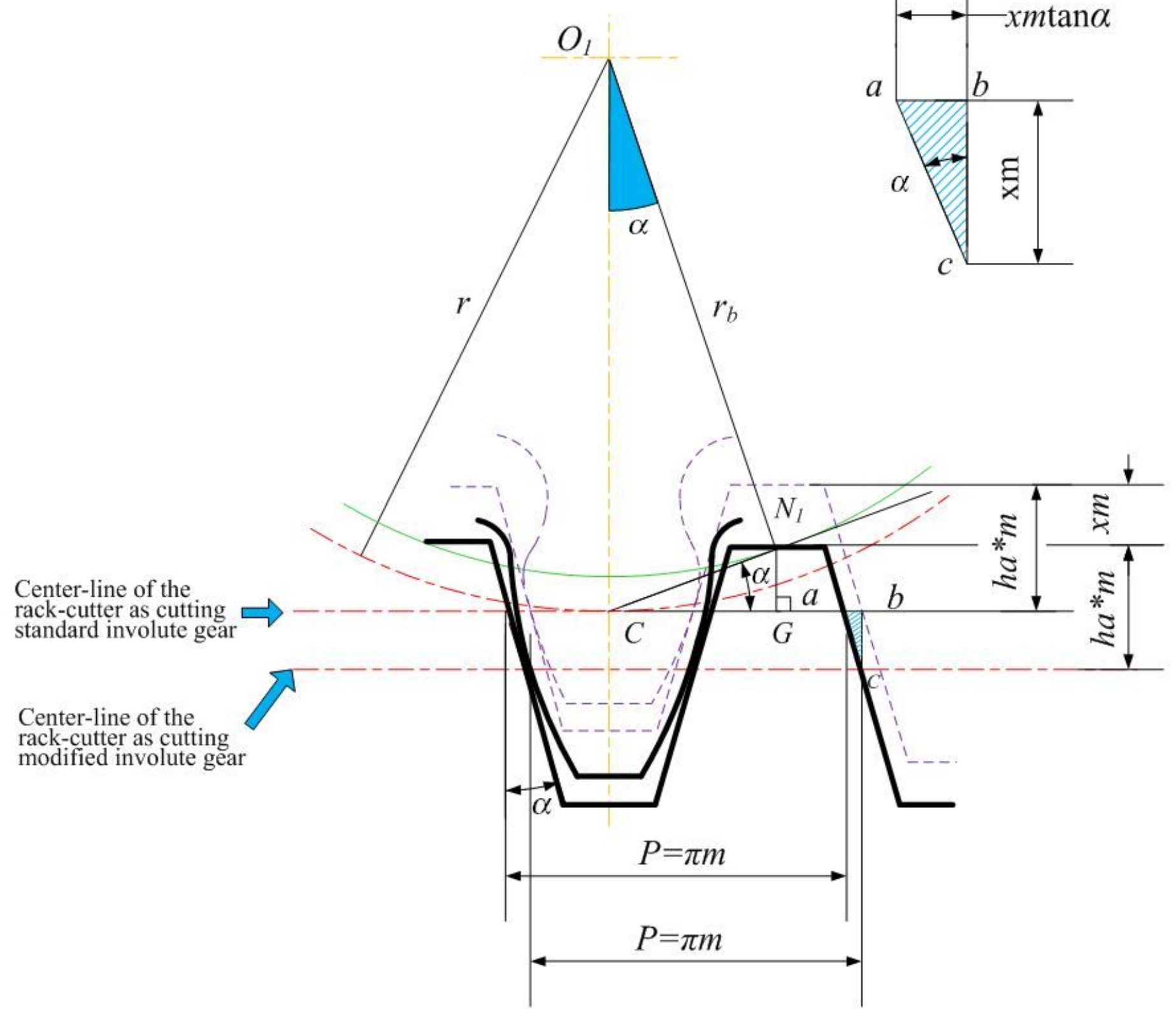

Figure 1

Undercut and modification of standard involute gear 


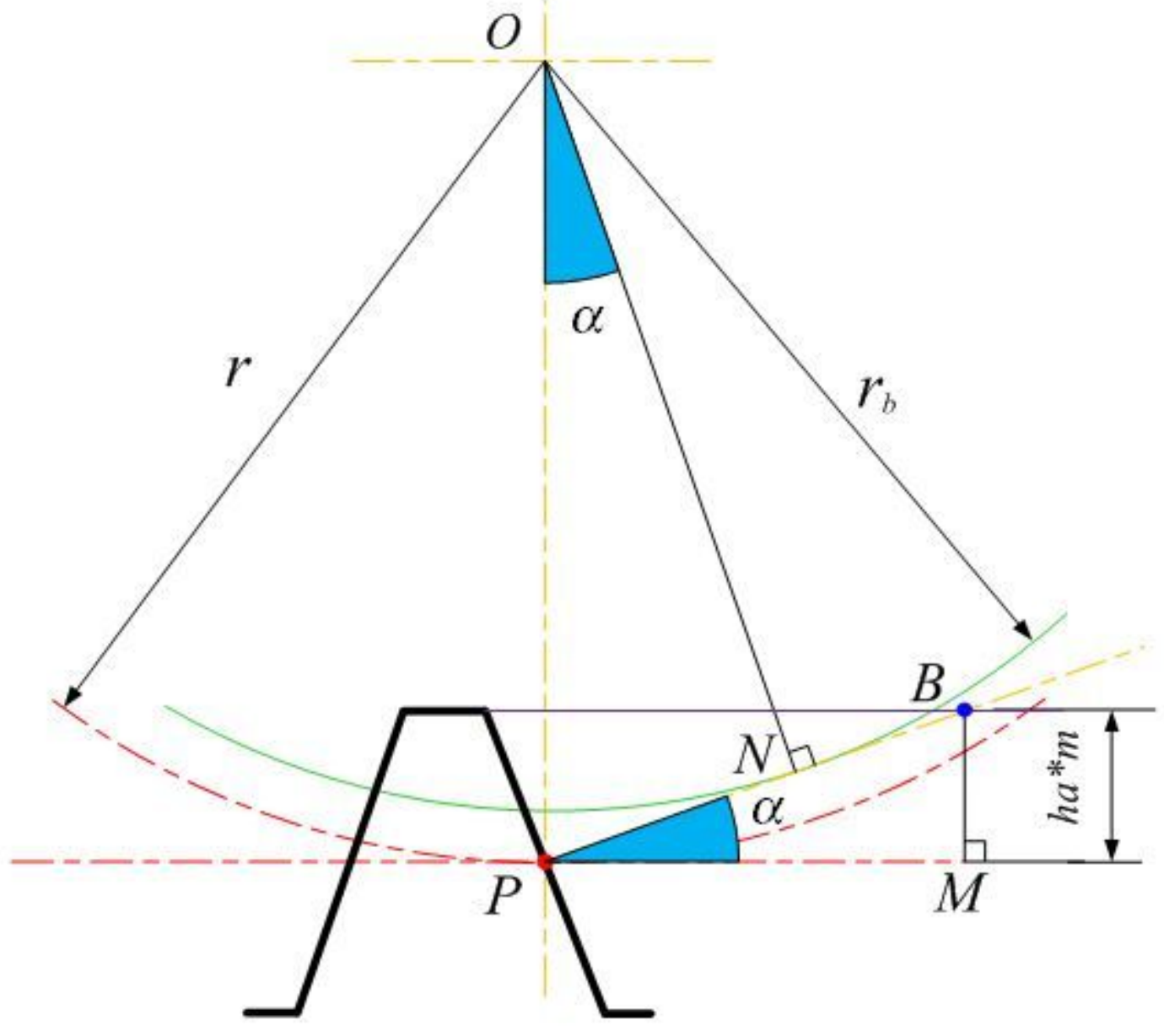

Figure 2

Diagram of traditional involute gear manufacturing with standard rack 


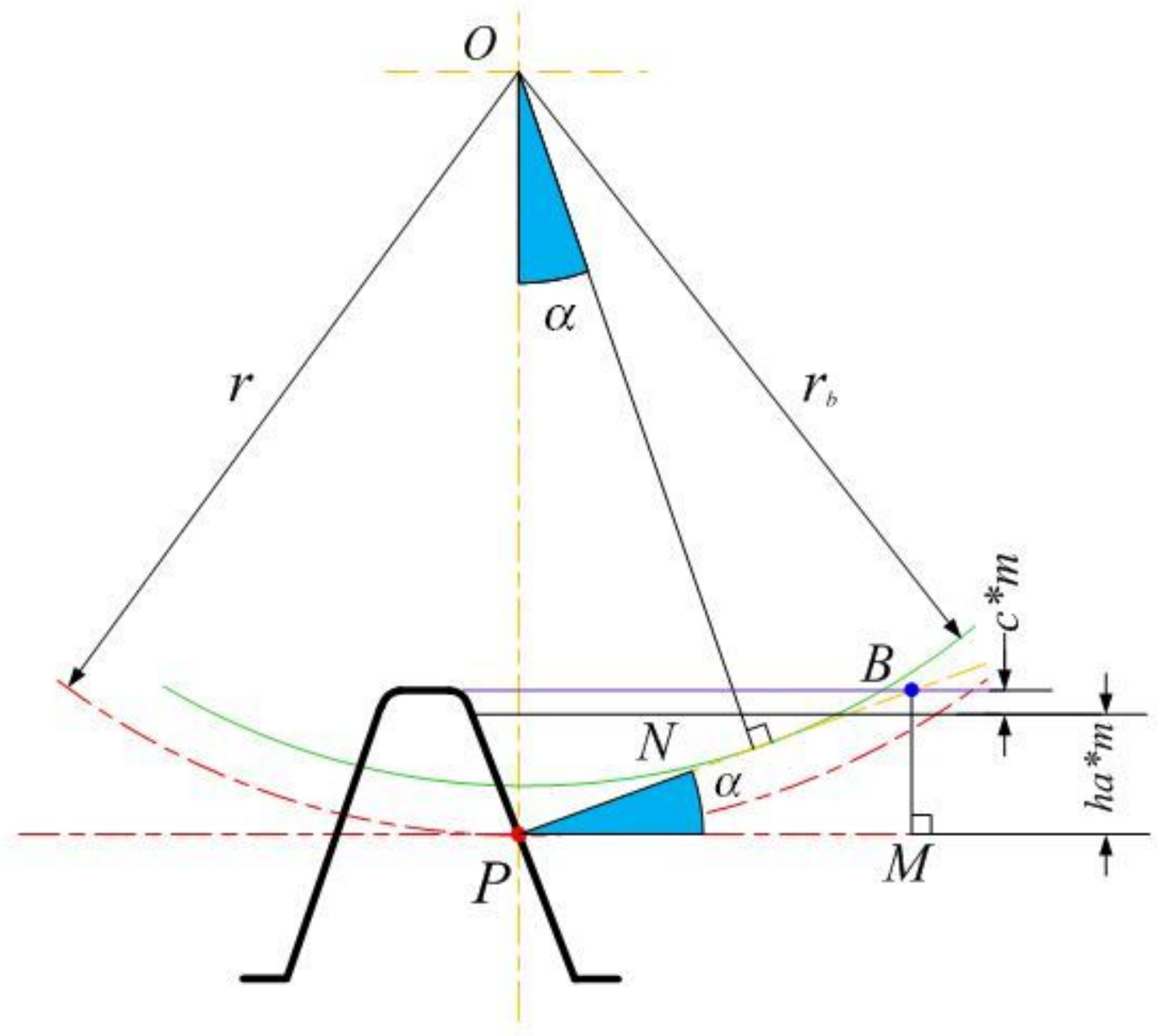

Figure 3

Standard involute gear manufacturing by a standard rack-shaped cutter 


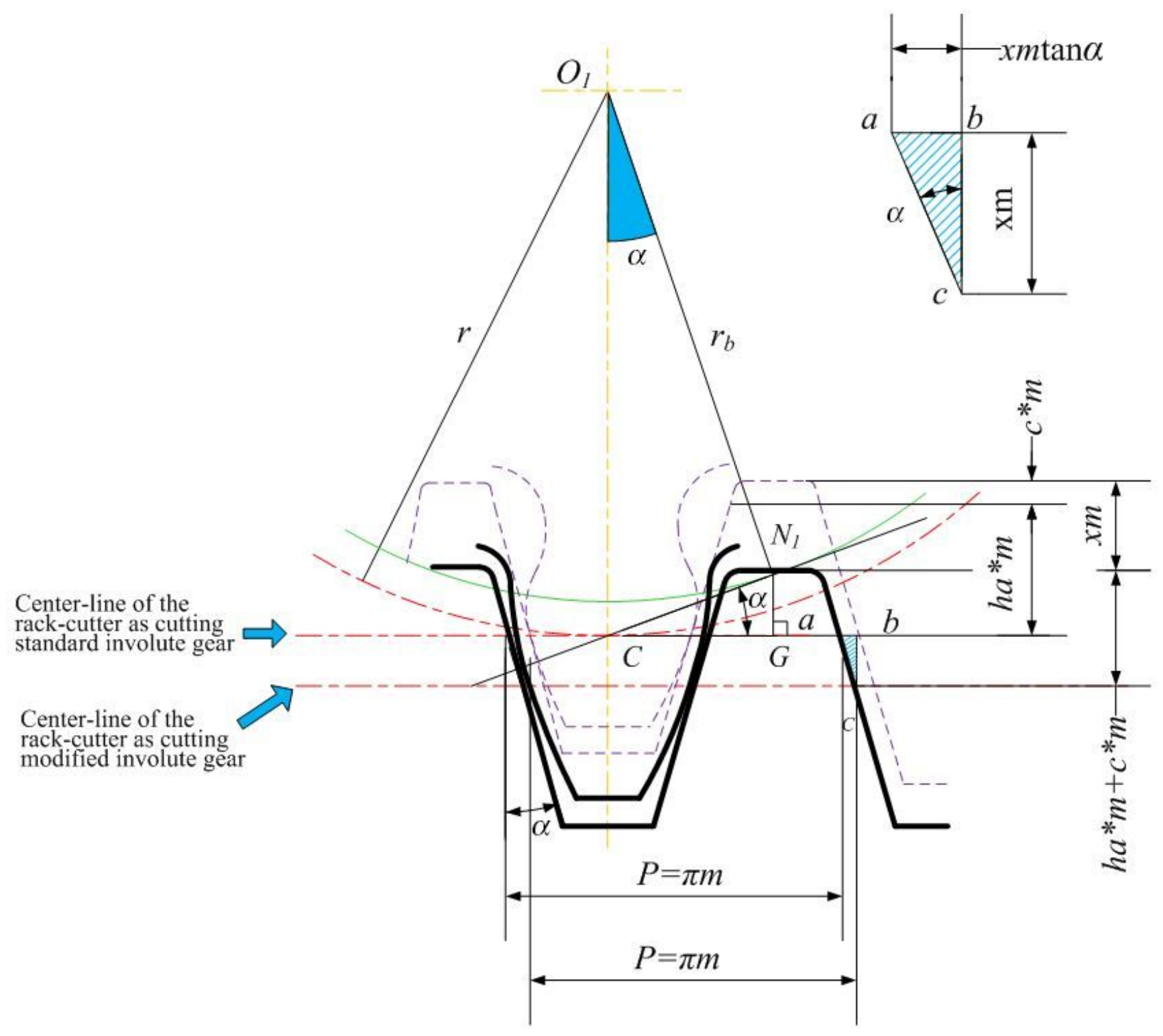

Figure 4

Undercut and modification of standard involute gear in practice 

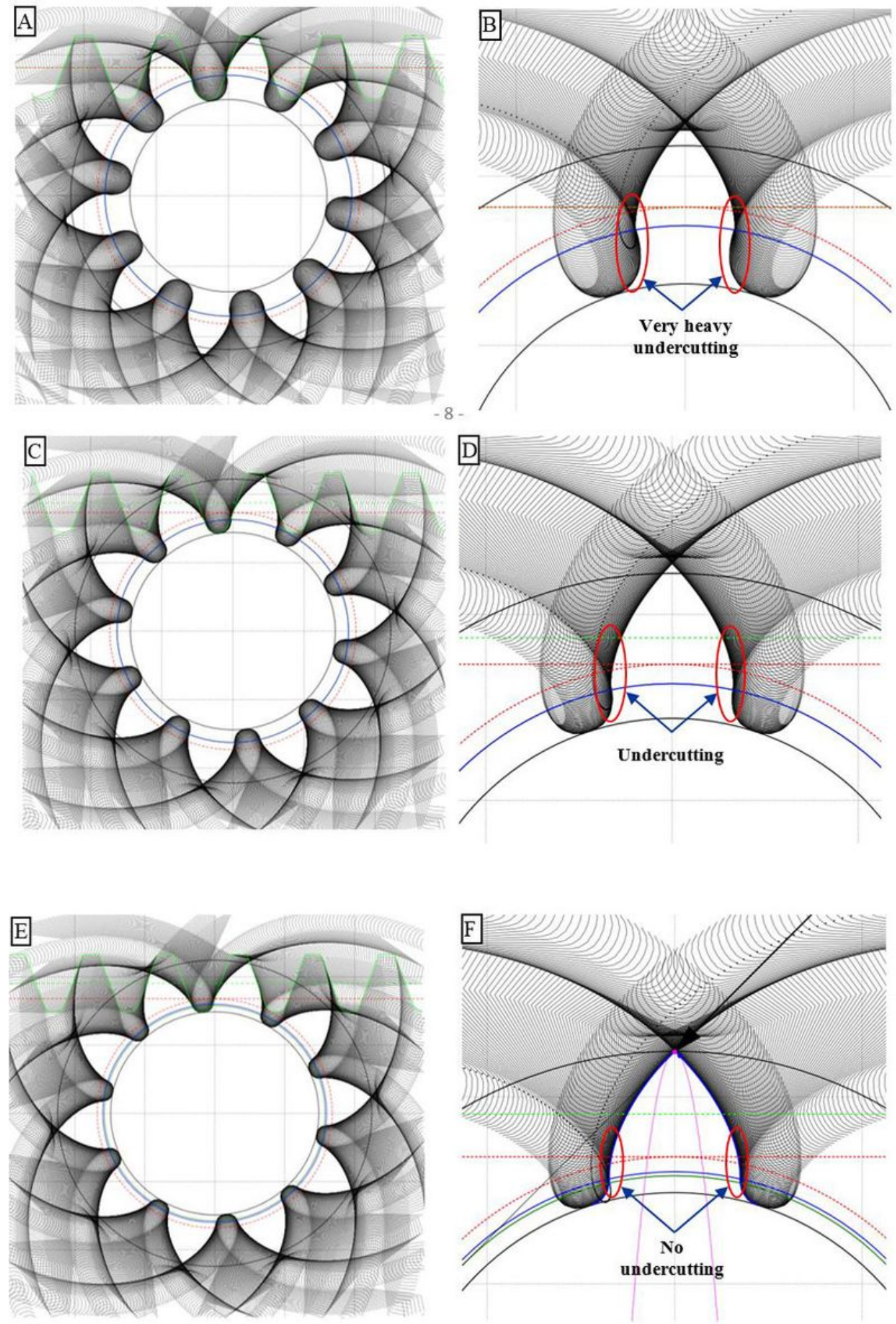

Figure 5

Representative simulated standard involute spur gear with $z=10$. A) Standard involute spur gear of $z=10$ without modification. B) Enlarged tooth profile of $z=10$ without modification. C) xmin=0.41. D) Enlarged tooth profile corrected with $x \min =0.41$. E) Standard involute spur gears of $z=10$ with $x \min =0.68$. F) Enlarged tooth profile of $z=10$ with $x \min =0.68$. 

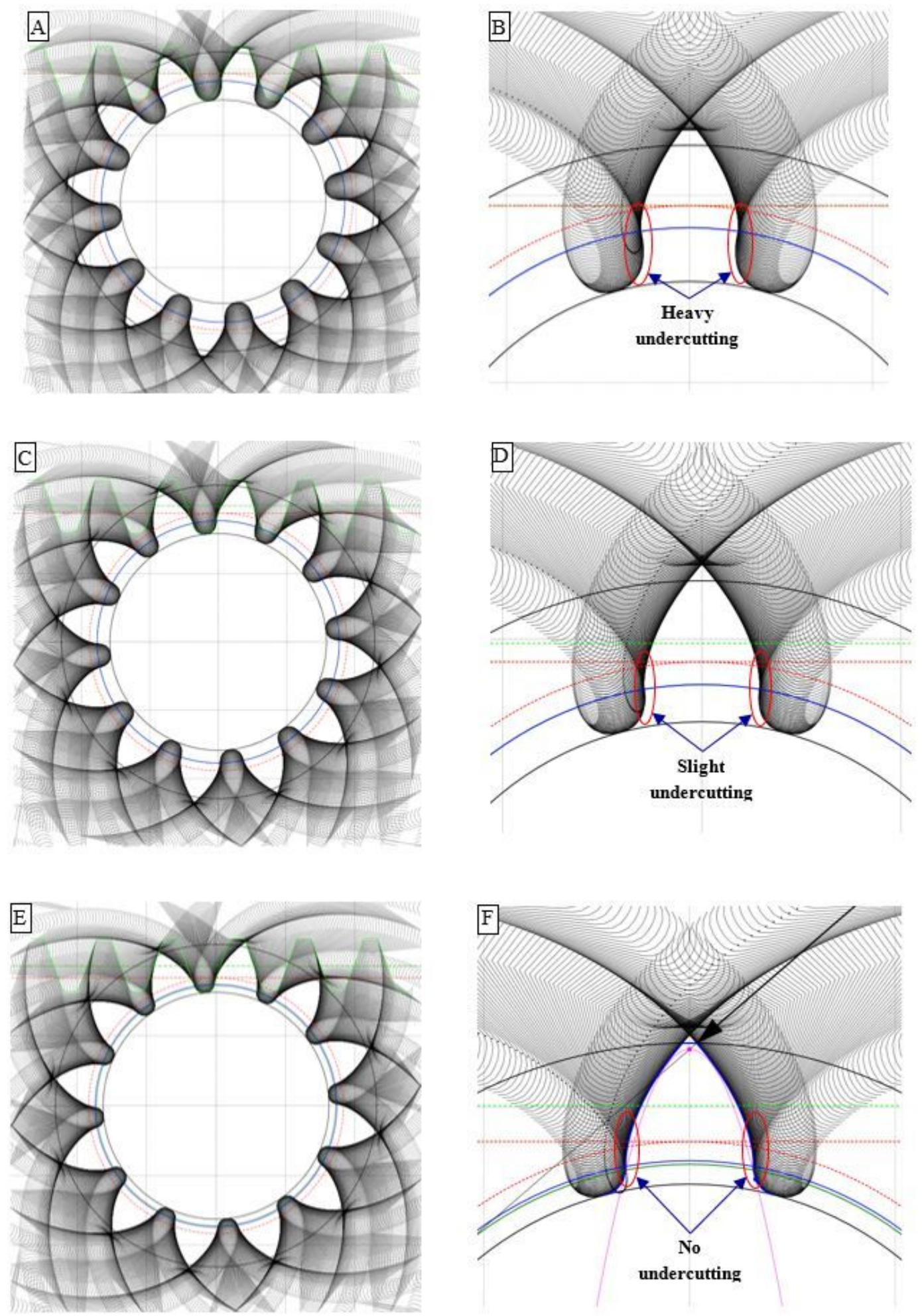

\section{Figure 6}

Representative simulated manufacturing drawing of spur gear with $z=12$. A) $x \min =0$. B) Enlarged tooth profile without modification. C) $x \min =0.29$. D) Enlarged tooth profile corrected with $x \min =0.29$. $E$ ) $x \min =0.57 . F)$ Enlarged tooth profile corrected with $x \min =0.57$. 

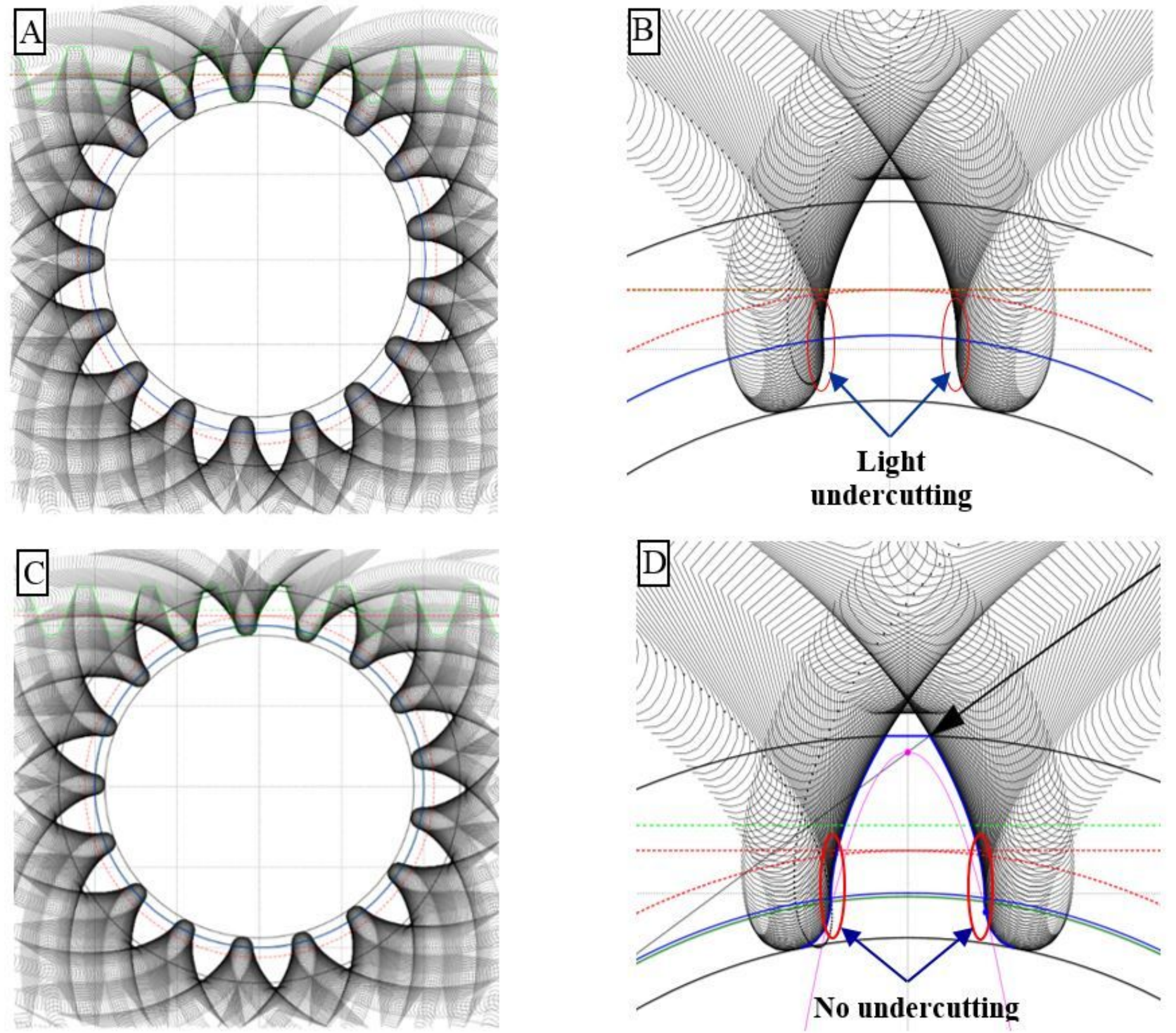

Figure 7

Representative simulated manufacturing drawing of $z=17$. A) Diagram of $z=17$ in conventional theory. B) Original tooth profile. C) Diagram of $z=17$ with $x \min =0.28$ (considering the effect of bottom clearance). D) Enlarged corrected tooth profile. 

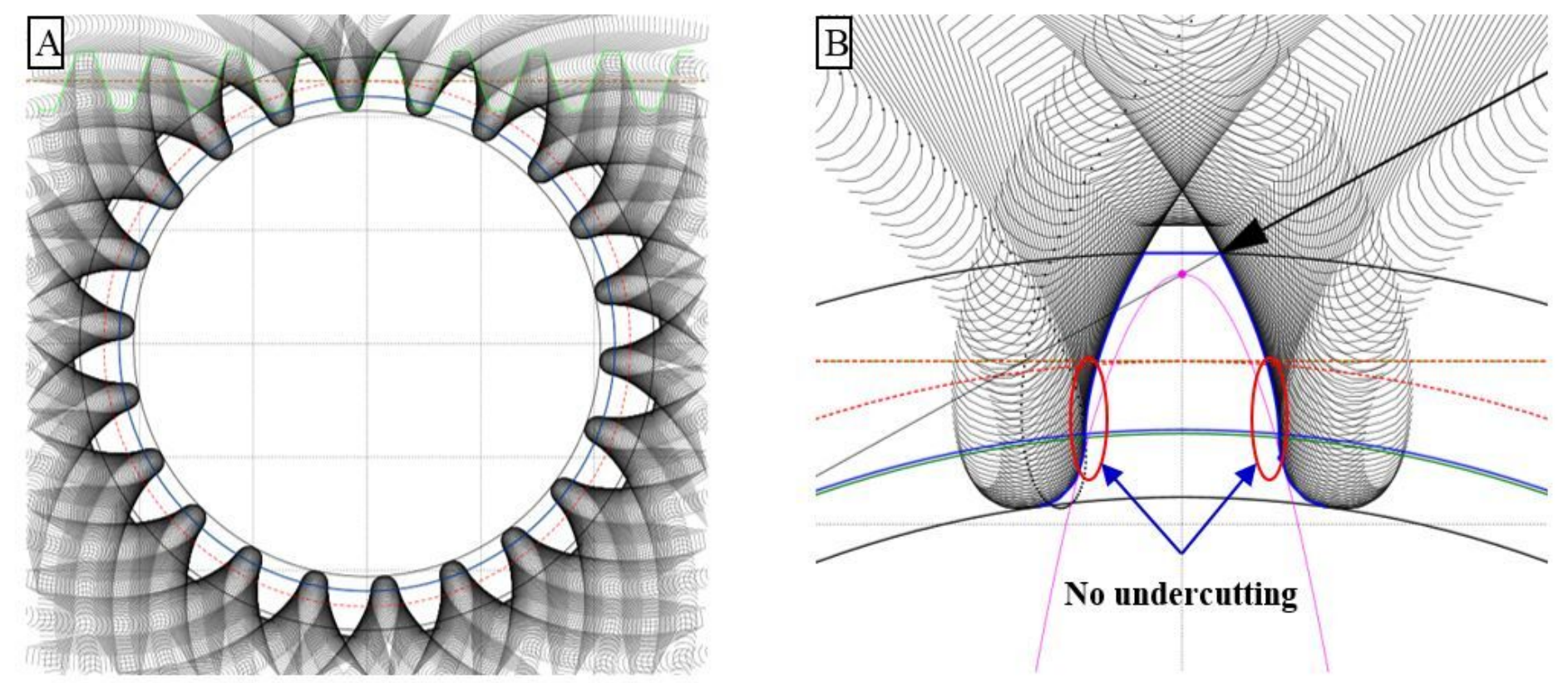

Figure 8

Representative simulated manufacturing drawing of $z=22$. A) Diagram of $z=22$ in conventional theory; $B$ ) Enlarged tooth profile.
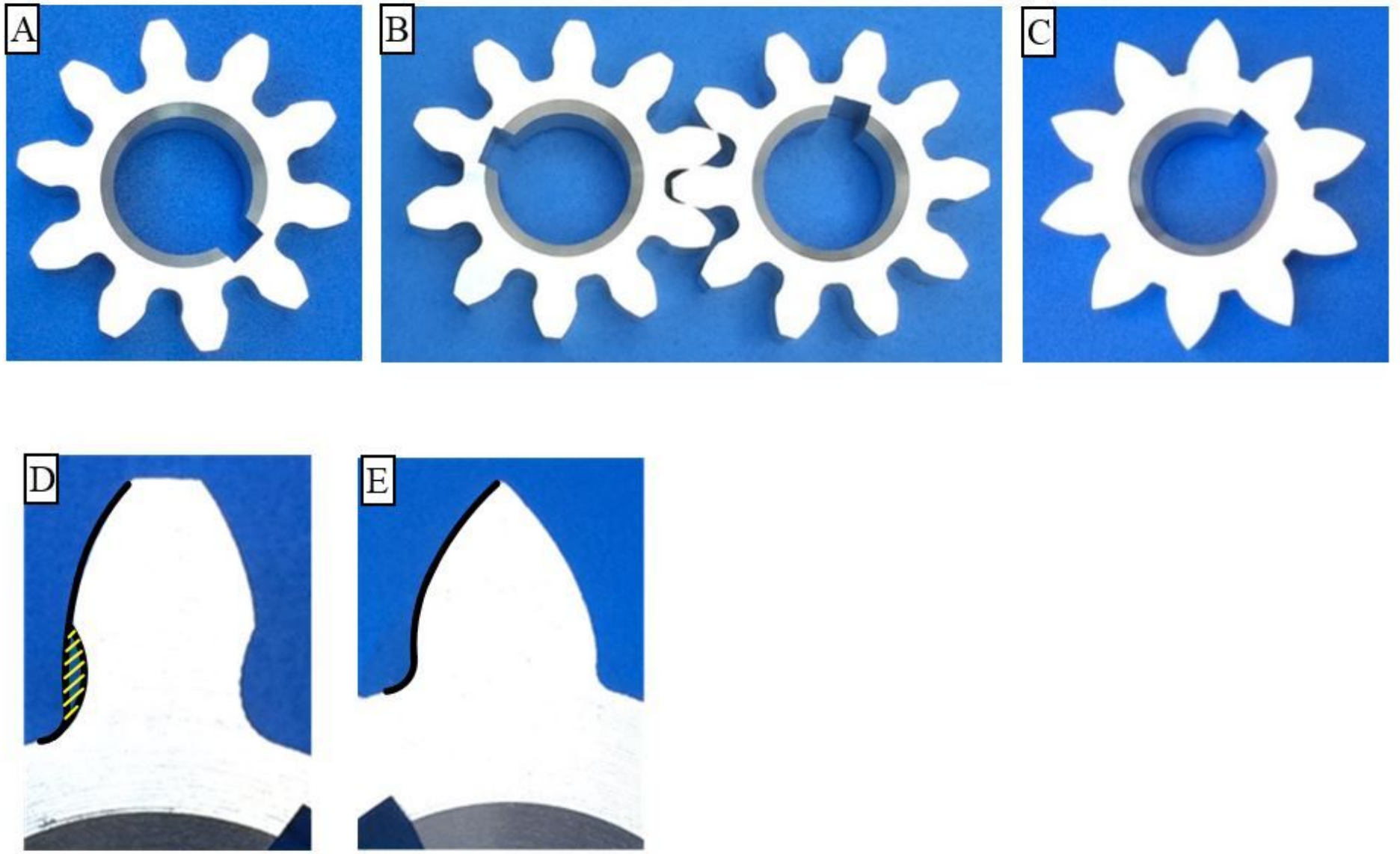

Figure 9 
Representative manufactured standard involute spur gear with $z=10$. A) Standard involute spur gear of $z=10$ without modification. B) Meshing diagram of two standard involute spur gears of $z=10$ without modification. C) Standard involute spur gears of $z=10$ with $x \min =0.68$. D) Enlarged tooth profile without modification. E) Enlarged tooth profile with modification.
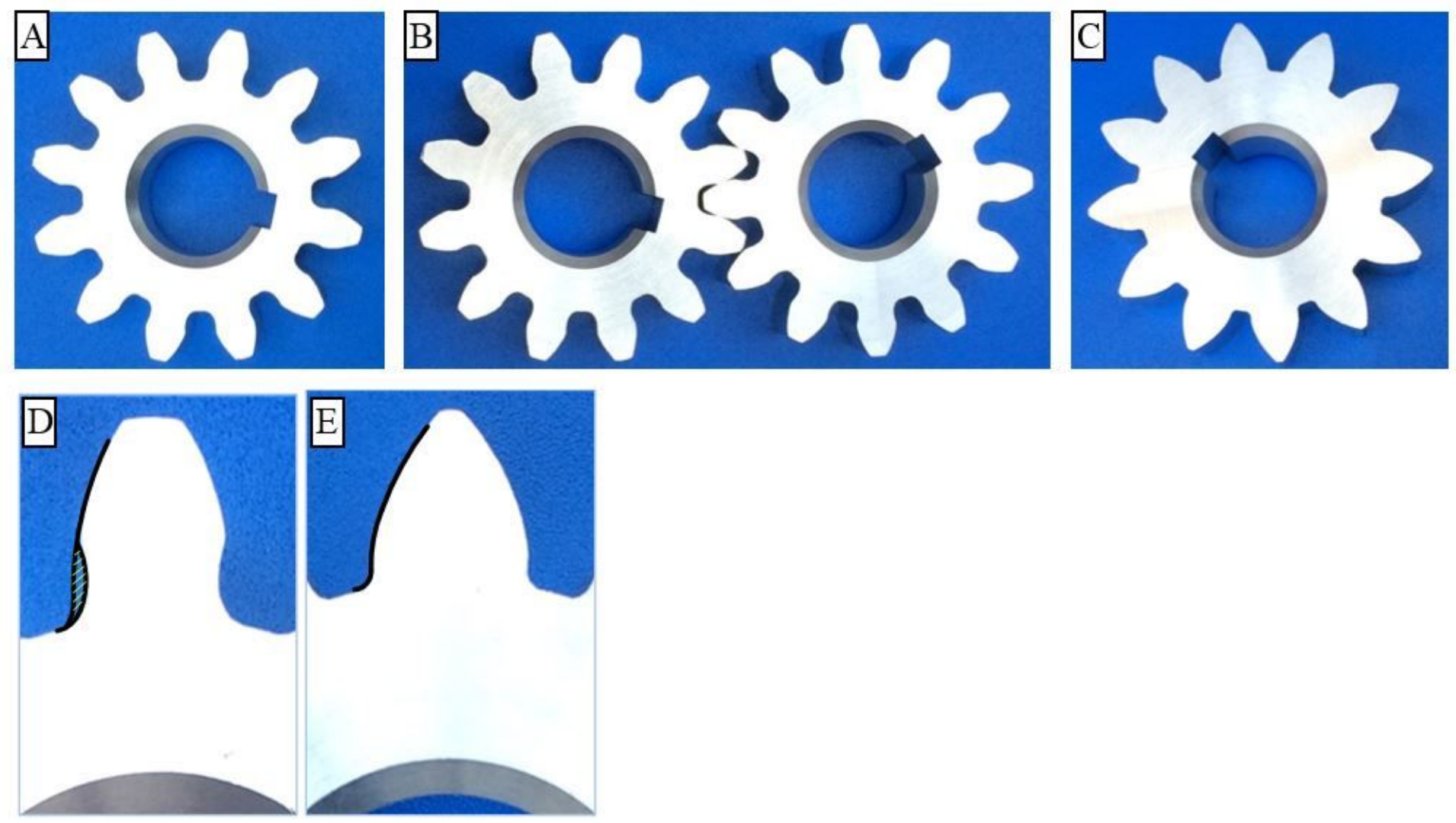

\section{Figure 10}

Representative manufactured standard involute spur gear with $z=12$. A) Standard involute spur gear of $z=12$ without modification. B) Meshing diagram of two standard involute spur gears of $z=12$ without modification. C) Standard involute spur gears of $z=12$ with $x \min =0.57$. D) Enlarged tooth profile without modification. E) Enlarged tooth profile with modification. 

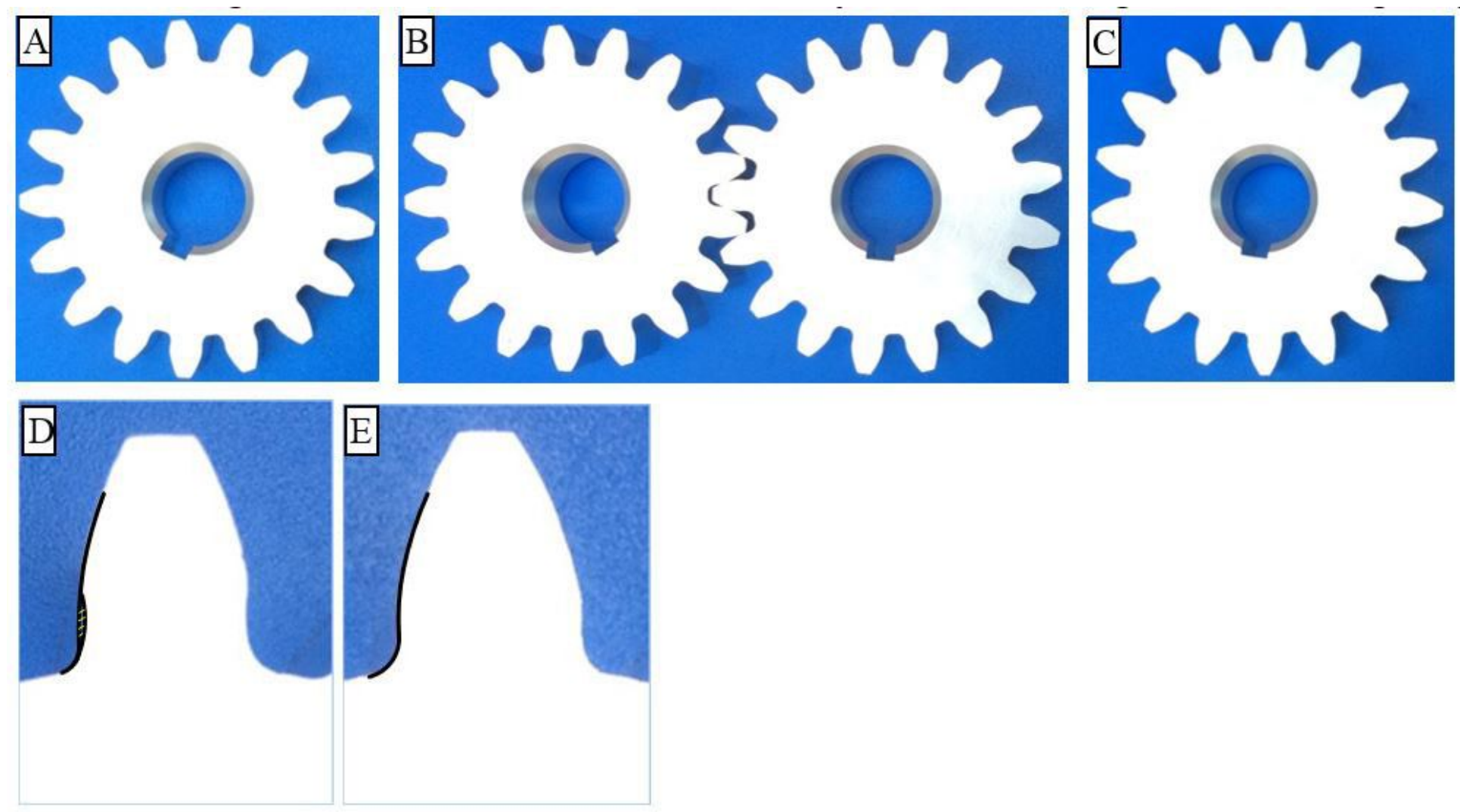

\section{Figure 11}

Diagrams of manufactured standard involute spur gear with $z=17$. A) Standard involute spur gear of $z=17$ without modification. B) Meshing diagram of two standard involute spur gears of $z=14$ without modification. C) Standard involute spur gears of $z=12$ with $x \min =0.28$. D) Enlarged tooth profile without modification. E) Enlarged tooth profile with modification.
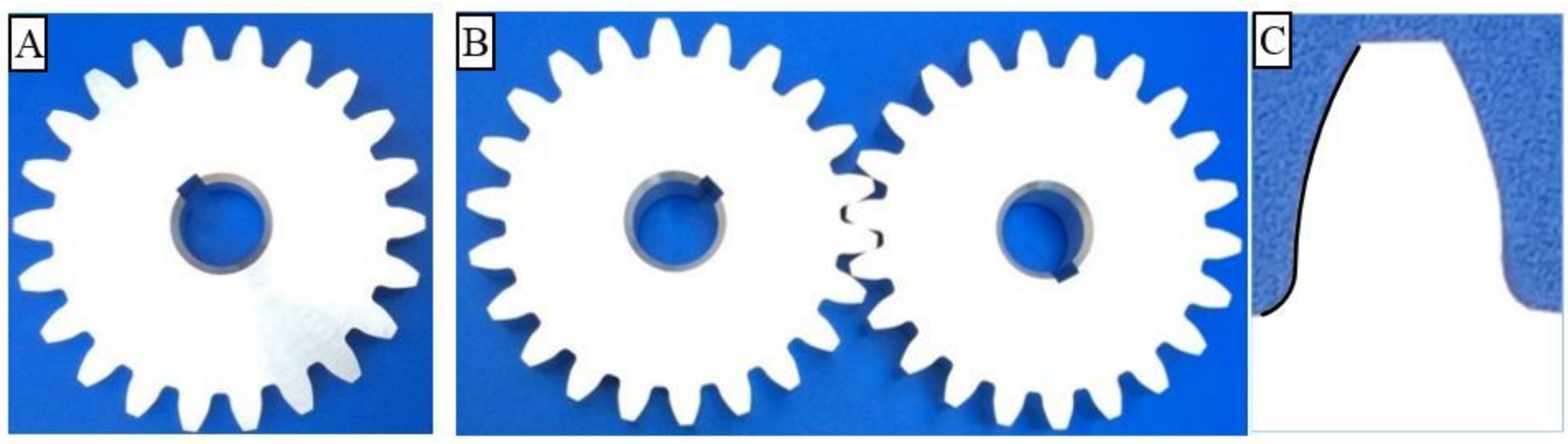

Figure 12

Representative manufactured standard involute spur gear with $z=22$. A) Standard involute spur gear of $z=22$ without modification. B) Meshing figure of two standard involute spur gears of $z=22$ without modification. C) Enlarged tooth profile without modification. 